2019-03-25

Urban blue: A global analysis of the factors shaping people's perceptions of the marine environment and ecological engineering in harbours.

\title{
Strain, EMA
}

http://hdl.handle.net/10026.1/13232

10.1016/j.scitotenv.2018.12.285

Science of the Total Environment

Elsevier

All content in PEARL is protected by copyright law. Author manuscripts are made available in accordance with publisher policies. Please cite only the published version using the details provided on the item record or document. In the absence of an open licence (e.g. Creative Commons), permissions for further reuse of content should be sought from the publisher or author. 


\section{Accepted Manuscript}

Urban blue: A global analysis of the factors shaping people's perceptions of the marine environment and ecological engineering in harbours

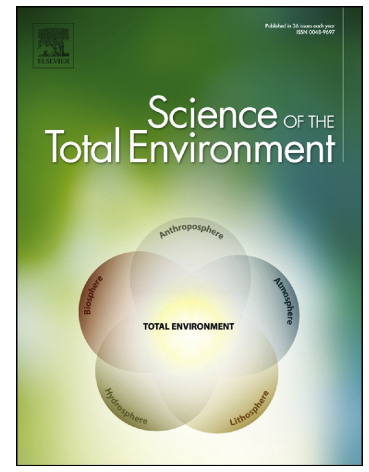

E.M.A. Strain, K. Alexander, S. Kienker, R. Morris, R. Jarvis, R. Coleman, B. Bollard, L.B. Firth, A.M. Knights, J.H. Grabowski, L. Airoldi, B.K.K. Chan, S.Y. Chee, Z. Cheng, R. Coutinho, R.G. de Menezes, M. Ding, Y. Dong, C.M.L. Fraser, A.G. Gómez, J.A. Juanes, P. Mancuso, L.V.R. Messano, L.P.D. Naval-Xavier, S. Scyphers, P. Steinberg, S. Swearer, P.F. Valdor, J.X.Y. Wong, J. Yee, M.J. Bishop

PII: S0048-9697(18)35158-1

DOI: https://doi.org/10.1016/j.scitotenv.2018.12.285

Reference: STOTEN 30119

To appear in: Science of the Total Environment

Received date: 26 October 2018

Revised date: 17 December 2018

Accepted date: 18 December 2018

Please cite this article as: E.M.A. Strain, K. Alexander, S. Kienker, R. Morris, R. Jarvis, R. Coleman, B. Bollard, L.B. Firth, A.M. Knights, J.H. Grabowski, L. Airoldi, B.K.K. Chan, S.Y. Chee, Z. Cheng, R. Coutinho, R.G. de Menezes, M. Ding, Y. Dong, C.M.L. Fraser, A.G. Gómez, J.A. Juanes, P. Mancuso, L.V.R. Messano, L.P.D. Naval-Xavier, S. Scyphers, P. Steinberg, S. Swearer, P.F. Valdor, J.X.Y. Wong, J. Yee, M.J. Bishop, Urban blue: A global analysis of the factors shaping people's perceptions of the marine environment and ecological engineering in harbours. Stoten (2018), https://doi.org/10.1016/ j.scitotenv.2018.12.285

This is a PDF file of an unedited manuscript that has been accepted for publication. As a service to our customers we are providing this early version of the manuscript. The manuscript will undergo copyediting, typesetting, and review of the resulting proof before it is published in its final form. Please note that during the production process errors may be discovered which could affect the content, and all legal disclaimers that apply to the journal pertain. 
Title: Urban blue: A global analysis of the factors shaping people's perceptions of the marine environment and ecological engineering in harbours

Authors: Strain, E.M.A. ${ }^{1,2,3}$; Alexander, K. ${ }^{4,5}$; Kienker, S. ${ }^{1,6}$, Morris, R. ${ }^{3,6}$; Jarvis, R. ${ }^{1,7}$;

Coleman, R. ${ }^{1,6}$; Bollard, B. ${ }^{7}$; Firth; L.B. ${ }^{8}$; Knights, A.M. ${ }^{8}$; Grabowski, J. H. ${ }^{9}$; Airoldi, L. ${ }^{10}$;

Chan, B.K.K. ${ }^{11}$; Chee, S. Y. ${ }^{12}$; Cheng, $\mathrm{Z}^{13}$; Coutinho, R. ${ }^{14}$; de Menezes, R.G ${ }^{15}$; Ding, $\mathrm{M}^{13}$.

Dong, Y. ${ }^{13}$; Fraser, C.M.L. ${ }^{11}$; Gómez, A.G. ${ }^{15}$; Juanes, J.A. ${ }^{15}$; Mancuso, P. ${ }^{10}$; Messano,

L.V.R ${ }^{14}$, Naval-Xavier, L.P.D. ${ }^{14}$; Scyphers, S. ${ }^{9}$; Steinberg, P. ${ }^{1,2}$; Swearer, S $^{3}$; Valdor, P.F. ${ }^{15}$;

Wong, J.X.Y. ${ }^{10}$; Yee, J. $^{12}$; Bishop, M.J. ${ }^{1,16}$

1 Sydney Institute of Marine Science, 19 Chowder Bay Rd, Mosman, New South Wales, Australia 2088

2 Centre for Marine Bio-Innovation, School of Biological, Earth and Environmental

Sciences, University of New South Wales, Sydney, New South Wales, Australia, 2052

3 National Centre for Coasts and Climate, School of Biosciences, The University of

Melbourne, Parkville, Victoria, Australia, 3010

4. Institute for Marine and Antarctic Studies, University of Tasmania, PO Box 49, Hobart, Tasmania, Australia, 7001

5. Centre for Marine Science, Socioecology, University of Tasmania, Hobart, Tasmania, Australia, 7001

6 University of Sydney, Centre for Research on Ecological Impacts of Coastal Cities, School of Life and Environmental Sciences, NSW 2006, Australia 
7. Institute for Applied Ecology New Zealand, School of Science, Auckland University of Technology, Auckland, New Zealand, 1142.

8. School of Biological and Marine Sciences, University of Plymouth, Plymouth, Drake Circus, UK, PL4 8AA

9. Marine Science Center, Northeastern University, 430 Nahant Road, Nahant, MA, USA, 01907

10. University of Bologna, Dipartimento di Scienze Biologiche, Geologiche ed Ambientali (BIGEA) \& Centro Interdipartimentale di Ricerca per le Scienze Ambientali (CIRSA), UO CoNISMa,Via S. Alberto, Ravenna, Italy, 163, I-48123

11. Biodiversity Research Centre, Academia Sinica, Taipei 115, Taiwan

12. Centre for Marine and Coastal Studies, Universiti Sains Malaysia, Penang, Malaysia 11800

13. State Key Laboratory of Marine Environmental Science, College of Ocean and Earth Sciences, Xiamen University, Xiamen, China 361102

14. Department of Marine Biotecnology, Instituto de Estudos do Mar Almirante Paulo Moreira, Brazilian Navy \& Post-Graduation Program in Marine Biotechnology, (IEAPM/UFF), Arraial do Cabo, Rio de Janeiro, Brazil, 28930-000

15. Environmental Hydraulics Institute, Universidad de Cantabria, Avda. Isabel Torres, 15, Parque Científico y Tecnológico de Cantabria, 39011 Santander, Spain

16. Department of Biological Sciences, Macquarie University, NSW, Australia, 2109 


\section{Abstract}

Marine harbours are the focus of a diverse range of activities and subject to multiple anthropogenically induced pressures. Support for environmental management options aimed at improving degraded harbours depends on understanding the factors which influence people's perceptions of harbour environments. We used an online survey, across 12 harbours, to assess sources of variation people's perceptions of harbour health and ecological engineering. We tested the hypotheses: 1) people living near impacted harbours would consider their environment to be more unhealthy and degraded, be more concerned about the environment and supportive of and willing to pay for ecological engineering relative to those living by less impacted harbours, and 2) people with greater connectedness to the harbour would be more concerned about and have greater perceived knowledge of the environment, and be more supportive of, knowledgeable about and willing to pay for ecological engineering, than those with less connectedness. Across twelve locations, the levels of degradation and modification by artificial structures were lower and the concern and knowledge about the environment and ecological engineering were greater in the six Australasian and American than the six European and Asian harbours surveyed. We found that people's perception of harbours as healthy or degraded, but not their concern for the environment, reflected the degree to which harbours were impacted. There was a positive relationship between the percentage of shoreline modified and the extent of support for and people's willingness to pay indirect costs for ecological engineering. At the individual level, measures of connectedness to the harbour environment were good predictors of concern for and perceived knowledge about the environment but not support for and perceived 
knowledge about ecological engineering. To make informed decisions, it is important that people are empowered with sufficient knowledge of the environmental issues facing their harbour and ecological engineering options.

\section{Keywords}

Estuaries and bays; urbanisation; coastal armouring; eco-engineering; stakeholders; human perceptions

\section{Introduction}

Harbours, coastal bodies of water that are sheltered by natural or artificial barriers (e.g. bays, ports and estuaries), have long served as the focal points of human settlement. Historically, harbours served as central hubs for trade and transport, with many locations also supporting commercial fishing industries (Pearson et al., 2016; Steinberg et al., 2016). More recently, human population growth and tourism around harbours has been fuelled by their high recreational and aesthetic value (Ghermandi and Nunes, 2013). By 2050, it is estimated that $50 \%$ of the world's populations will live in coastal cities, with many in harbour cities (Firth et al., 2016; McGranahan et al., 2007; Small and Nicholls, 2003).

The high value that society has placed on harbours for living, working and recreation has made them some of the most heavily modified environments on earth (Lotze et al., 2006). Anthropogenic threats to harbour environments include pollution, overexploitation of resources, habitat loss and degradation and species introductions (Airoldi and Beck, 2007; 
Crain et al., 2009). Additionally, in many harbours, artificial structures (e.g. seawalls, groynes, breakwaters, wharves) built to reclaim land, support shipping, fishing and recreational activities (Strain et al., 2018b) are now the dominant habitat type, replacing natural shorelines and marine ecosystems such as mangrove forests, seagrass beds, saltmarshes, and rocky and sedimentary shores (Heery et al., 2017; Lai et al., 2015; Prosser et al., 2017). These artificial habitats can have a myriad of negative impacts on native biodiversity and ecosystem functioning (Chapman and Underwood, 2011).

As awareness of the extent of harbour modification has grown, so too has scientific interest and investment in environmental management programs aimed at mitigating stressors, "greening" of artificial structures (hereafter termed ecological engineering) and rehabilitating lost or degraded ecosystems. Ecological engineering approaches include modifying the attributes of existing artificial structures (e.g. adding artificial rock pools, termed hard ecological engineering), replacing artificial structures with created or restored natural habitats (e.g. oyster reefs, termed soft ecological engineering), or combining created or restored natural habitats with artificial structures (e.g. mangroves with rocksills, termed hybrid ecological engineering) (Chapman and Underwood, 2011). While the most appropriate approach will depend on the environment as well as on engineering, ecological and socioeconomic objectives, all projects have a common goal of building structures that benefit both humans and nature (Mitsch, 2012).

The success of such environmental management in achieving its goals is dependent on knowledge of how coastal marine ecosystems work, technical capacity and funding, legal permitting, politically willingness as well as on social acceptance (Cormier and Elliott, 2017; 
Elliott, 2013; Menz et al., 2013). Despite use of the best available environmental information, many conservation initiatives fail because affected stakeholders are not supportive of the desired actions (Ban et al., 2013; Jarvis et al., 2016). Understanding the attitudes, preferences, and behaviours of stakeholders, can assist in tailoring interventions to communities, and in ensuring compliance with recommendations (Ban et al., 2009). Support for ecological engineering often varies predictably among stakeholder groups, within harbours (Derkzen et al., 2017; Evans et al., 2017; Gray et al., 2017; Kienker et al., 2018; Liu et al., 2018; Morris et al., 2016; Smith et al., 2017; Strain et al., 2018a). Nevertheless, there are relatively few studies examining public perceptions of the overall health of harbour environments, and levels of environmental concern (Easman et al., 2018; Jarvis et al., 2015) and knowledge and willingness to contribute to the costs of ecological engineering initiatives, particularly in developing countries. Moreover, this information will assist ongoing efforts to implement ecological engineering initiatives aimed at protecting and restoring urban harbours.

Public perceptions of environmental health, their concern for the harbour environment and people's support of management interventions may be expected to vary spatially according to their usage of the environment (Kienker et al., 2018; Pacione, 2003), the distance they live from the waterway (Atkins et al., 2007), socio-economic status (Franzen and Meyer, 2009; Roca and Villares, 2008) and cultural factors (Madureira et al., 2015; Madureira et al., 2018; Priego et al., 2008). People's awareness of human impacts on their geographic location (Kienker et al., 2018) and proximity to degraded environmental locations (Gifford and Nilsson, 2014) may also influence people's perception of the harbour environment. At a local level, factors such as age, gender, income and education, and political ideology can be strong predictors of environmental concern in terrestrial environments (Fransson and Gärling, 1999; Liere and Dunlap, 1980). There is however, limited research on whether the factors that 
influence human perceptions of urban terrestrial environments (Ambrosius and Gilderbloom, 2015; Priego et al., 2008; Van den Berg et al., 2007) also apply to marine harbours. The development of an international and cross-cultural understanding of factors influencing human perceptions of harbour health and degradation, will help in developing strategies for building public support of management interventions (Franzen and Meyer, 2009; Jarvis et al., 2016; Pacione, 2003).

At, at an individual level, perceptions of the harbour environment could be influenced by a person's connectedness to the harbour (Kienker et al., 2018). Studies have demonstrated that individuals who engage with nature frequently have a greater concern for the environment (Beery and Wolf-Watz, 2014; Gunderson, 2006; Nisbet et al., 2009; Raymond et al., 2010). Individuals connect to harbours in a variety of ways: work (e.g. commercial fishing, shipping, transportation, environmental management, science), transport (e.g. ferries), leisure (e.g. boating, swimming, recreational fishing, jogging/walking on the foreshore), culture (e.g. festivals, social gatherings or indigenous links) and by living nearby (Pearson et al., 2016). In terrestrial and coastal environments, a positive relationship exists between connection to place, including amount of time spent there by non-residents (Kelly and Hosking, 2008), and for residents, residency length (McCool and Martin, 1994). In some locations, the increasing connection and use of place can also cause increased damage to the surrounding environment (Kelly and Hosking, 2008). It is unclear however, whether these relationships extend to aquatic environments, where people typically live and work alongside the harbour environment rather than within it. 
In this study, we assessed the sources of variation in perceptions towards harbour health and ecological engineering across twelve globally distributed locations using an online survey. We specifically focused on ecological engineering, amongst other management interventions, because it is an emergent approach, that is increasingly being utilised to 'green' grey infrastructure (Borsje et al., 2011; Chapman and Underwood, 2011; Mitsch, 2012). Specifically, we tested the hypotheses that: 1) people living by more impacted harbours would be more likely to consider their harbour environment unhealthy and degraded, be more concerned about the environment, be more supportive of ecological engineering and willing to contribute to the costs of ecological engineering projects than those living by less impacted harbours, and 2) people with greater connectedness to the harbour would be more concerned about and have greater perceived knowledge about the harbour environment, and be more supportive of, knowledgeable about and willing to contribute to the costs of ecological engineering, than those with less or no connectedness.

\section{Methods}

\subsection{Study sites}

The survey was conducted in twelve harbours worldwide (Fig. 1). Harbours were selected based on their participation in the World Harbour Project (http://worldharbourproject.org) and had varying levels of harbour modification, environmental stressors, population density and socio-demographics (Aguirre et al., 2016; Airoldi et al., 2016; Chee et al., 2017; Knights et al., 2016).

\subsection{Questionnaire}


The survey assessed perceptions towards each harbour of people living, working or recreationally using foreshore areas within two kilometres of its waterways. It used both targeted (coastal managers and marine scientists) and convenience sampling (all other stakeholder groups) to capture the responses of multiple user groups (Kemper et al., 2003), broadly following the methodology reported in Kienker et al. (2018) and Strain et al. (2018). This type of sampling was chosen as the best possible method for comparing multiple harbours across countries (Brown and Weber, 2012; Jarvis et al., 2015). It is an important sampling technique for raising public awareness of key issues and can contribute to more effective, durable and holistic decision and policy-making processes (Brown and Kyttä, 2014; Jarvis et al., 2015; Reed, 2008), however, it can be challenging to obtain a representative sample of the population (Blair et al., 2013).

To address these potential limitations, we sampled respondents at a variety of locations within each harbour, including street locations, shopping malls, private businesses and social events. The survey was also distributed online to people 18 years of age or over, and participants were recruited through advertisements on community boards, business cards, emails, social media, newsletters, mailing lists, or in person (using a tablet or paper copy of the questionnaire) along the foreshore of each harbour. In addition, the responses of specific user groups (i.e. coastal managers and marine scientists) were solicited through direct emails, meetings, and social events. All respondents were provided with access to the participant information sheet (ethics approval reference number H16175 University of NSW, Australia) before agreeing to undertake the survey (Fig S1). 
The survey was made available online through Surveymonkey (www.surveymonkey.com) or REDcap (Harris et al., 2009) between June and December 2017. The survey required approximately 10-15 minutes to complete and included 19 questions on three themes: harbour use, views on artificial structures and perceptions of ecological engineering. In this study, 15 questions were used in the analyses (Fig. S2). In all locations, the survey was presented to the respondents in their local language (i.e. English, Italian, Portuguese, Malay, Mandarin or Spanish), and for the subset of questions where pictures of man-made structures and ecological engineering initiatives were included, the examples were provided from the local harbour environment (Fig. S2). During the survey, we collected information about the percentage of their income the participants gained from the harbour and their individual income bracket per year (before tax). The individual income categories (very low, low, average, high and very high) for each location were determined from income brackets reported by the most recent government census data (either at city - Sydney, Melbourne, Auckland, Arraial do Cabo, Boston, Keelung, Santander or country level - Ravenna, Plymouth, Penang and Xiamen). The survey included questions with multiple choice, binary (yes or no) and 5-point Likert scale (2 answers in agreement with the statement, 1 neutral answer and 2 answers in disagreement with the statement) answers. This mix of multiple choice, binary and Likert scale answers allowed us to explore multiple perspectives. In all locations, participation in the survey was voluntary and without incentive.

\subsection{Analyses}

To assess the extent to which the survey sample was representative of the broader population at each location, we used binomial tests to assess any differences in sex ratios, age brackets and education levels, between our survey and the most recent government census of the 
population (see Table S4 for full details). For many locations, there was limited or no information available about the individual annual income brackets at the city level. Therefore, for all locations, we only tested for differences in the average annual income between the survey and census populations.

To assess the relationships between the status of the harbour environment and people's perceptions, two independent measures of impacts were calculated for each harbour (Table S3). The first was the cumulative impact index, which gives a relative measure of the intensity of human pressures in the harbour environment, for each country (average highest impact) through time, globally (Halpern et al., 2008). High scores (>12) are indicative of impacted systems, whereas low scores $(<4.95)$ indicate less impacted systems (Halpern et al., 2008). The second metric of impact was the percentage of the harbour shoreline (main body of water only and excluding all tributaries) that was modified by artificial structures such as coastal defences, retaining walls, marinas and jetties, and other public amenities. The percentage of harbour shoreline modified by artificial structures was estimated and mapped from satellite images in Google Earth using images from 2016-2017 (Table S3). To ground truth this information, we also checked the figures estimated from Google Earth against existing values from the literature (Table S3). To explore the relationships between each of the two independent measures of impact and the perceptions towards harbour health and connectedness of individual people to harbours (see below details) across locations, we used principal components analysis (PCA). All variables were normalised to account for differences in measurement scales.

We used ordinal regression models to separately assess the relationship between the two measures of impact and the individual respondent's perceptions of harbour health (ordinal 5- 
point Likert-scale) and harbour degradation (ordinal 5-point Likert-scale), their concern for the harbour environment (ordinal 5-point Likert-scale) and their willingness to contribute to the costs of ecological engineering projects through donating money, paying government taxes or voting to ensure businesses included the costs in future developments (ordinal 5point Likert-scale). Generalised linear models with a binomial distribution were used to assess whether people's support for ecological engineering (yes or no) varied as a function of the cumulative impact index or the percentage of harbour shoreline modified.

Four separate measures were used as indicators of people's connectedness to the harbour. These were: type of use ( 7 fixed levels = I don't use the harbour vs. culture, leisure, property, transport, paid work, unpaid work); frequency of use (8 fixed levels = I don't use the harbour, $<1$ visit per year, 4-6 months, 2-3 months, monthly, weekly, daily, I live here); percentage of income from the harbour (covariate, 7 levels = none, unknown, $<10 \%, 11-20 \%, 21-50 \%, 51-$ $80 \%,>81 \%$ ) and number of years living on the harbour (covariate, 8 levels = I don't live here, <1 year, 1-2 years, 3-5 years, 6-10 years, 11-15 years, 16-20 years, >21 years). Using ordinal regression models, we assessed how each of these measures of connectedness varied among harbours (12 random levels) and explored if they were related to a respondent's (at the individual level) concern for the harbour environment (ordinal 5-point Likert scale), perceived knowledge of the harbour environment (ordinal 5-point Likert scale), perceived knowledge of ecological engineering (ordinal 5-point Likert scale) and willingness to contribute to the costs of ecological engineering projects through donating money, paying government taxes or voting to ensure businesses included the costs in future developments (ordinal 5-point Likert scale). To assess how support for ecological engineering (yes or no) varied as a function of these measures of connectedness and harbour (12 random levels), we used generalised linear models with a binomial distribution. For all analyses, we tested and 
found no effects of over dispersion using the AER library (Kleiber and Zeileis, 2008). The statistical significance $(\mathrm{p}<0.05)$ of each fixed and random effect was determined by undertaking likelihood ratio tests on models with and without each effect. For all models, we calculated odd ratios and confidence intervals as a measure of the effect size for all significant dependent variables. All analyses were conducted in R version 3.4 ( $\mathrm{R}$ Development Core Team, 2018).

\section{Results}

\subsection{Participation rate and demographics}

In total, 2392 people completed the survey, with 439 responses from coastal managers and marine scientists and 1953 responses from other stakeholders. Across the twelve locations there were 159 respondents who did not use or live by the harbour, and their responses were excluded from all analyses. The number of respondents per harbour ranged from 134 to 348 (Fig. 1). The responses per harbour is comparable to those used by other public perceptions studies on harbours (Evans et al., 2017; Kienker et al., 2018; Morris et al., 2016; Strain et al., 2018a). Across the locations, most (>73\%) of the participants completed the survey in their native language and identified their understanding of the questions as either average or good (Table 1).

The sample demographics varied among the twelve harbours (Table 1). In most harbours, there were approximately equal numbers of males and females surveyed, with the most common age categories 18-34 or 35-54 years, the most common highest education levels either a college or technical and further education (TAFE) diploma or certificate, bachelor's 
or higher degree, and the most common individual annual income categories low to very low (Table 1). In Melbourne, Sydney, Plymouth and Santander however, there were more people who reported an individual income per year that was average rather than low or very low (Table 1). In most locations, the percentage of males and females surveyed (excluding Plymouth and Santander) reflected the sex ratio of census data (Tables 1 and S5).

Additionally, of the eight harbours for which census income data were available, in six (Arrarial do Cabo, Santander and the four harbours of Australasia sampled), the percentage of people surveyed who earned the average individual income per year was comparable to census data (Tables 1 and S5). In contrast, in Penang, Keelung and Xiamen, the respondent's personal income per year (before tax) was significantly less in this study than the census data. In many locations, the percentage of survey respondents with bachelor or postgraduate degrees was greater than the general population, and in almost all locations, the age groups of 18-34 (with exceptions of Melbourne and Hobart) and 35-54 (with exceptions of Sydney, Plymouth and Xiamen), were overrepresented compared to the census data (Table 1 and S5).

\subsection{Differences between locations in harbour environment and people's perceptions}

There were key differences among locations in the levels of degradation, percentage of harbour shoreline modified and people's perception of the harbour environment and of ecological engineering, and their connectedness to the harbour environment (Table 2). The PCA analyses indicated that there were 5 axes with eigen values that were higher than 1 and accounted for $60.7 \%$ of the variance in the data. There was clear seperation in the levels of impact, people's perceptions of the harbour environment and ecological engineering and their connectness to the harbour between Asia/Europe and Australasia/America (Fig S6). 
The cumulative impact index and percentage of harbour shoreline modified were generally higher in the six European and Asian than the six Australasian and American harbours, surveyed (Table S3). The survey indicated people in Australasia and America generally had moderate to high concern for the environment, and average to good perceived knowledge of their harbour environment relative to people that were surveyed in Europe and Asia, who generally reported average concern for the environment and had average perceived knowledge of their harbour environment (Table 2). Across all locations, there was very high support for ecological engineering ( $>88 \%$ ). Most respondents were in favour of paying government taxes (excluding Arrarial do Cabo, Ravenna, Plymouth, and Penang) to fund ecological engineering and mandating businesses to include the costs of ecological engineering in future developments (all locations) but were unwilling to personally donate money towards the costs of ecological engineering (excluding Xiamen). Their perceived knowledge of ecological engineering was generally average to poor (Table 2).

In eight of the the twelve harbours, including six of the seven Australasia and Europe harbours survey (the exception being Plymouth as well as Boston and Keelung), the greatest reported use of the harbour was for lesuire activities (Table 2). In contrast, in Arrarial do Cabo paid work was the most common harbour activity, in Penang most people used the harbour for transport and in Xiamen most people used the harbour for lesuire and transport activities (Table 2). The respondents in Australaisa, Arrarial do Cabo, Plymouth and Santander generally lived alongside the harbour, while people in other locations whilst not living be the harbour but visited it throughout the year (Table 2). In all locations, the majority of respondents gained no income from the harbour (Table 2). In the four Australaisan harbours and Arrarial do Cabo, most of the respondents had lived by the harbour for over 21 years (Table 2). 


\subsection{Relationships between harbour environment and people's perceptions}

Across the twelve harbours, people's perception of their harbour environment varied according to the status of the harbour environment, as measured by either the cumulative impact index or the percentage of harbour shoreline modified by artificial structures (Fig. 2, Tables 3 and S7). The people in countries with a higher cumulative impact index were more likely to disagree or strongly disagree that "the harbour environment is generally healthy" and agree or strongly agree that "the harbour environment has been degraded by human development" (Fig. 2, Tables 3 and S7), compared with those in countries with a lower cumulative impact index. Similarly, the respondents in locations with a greater percentage of harbour shoreline modified by artificial structures were more likely to disagree or strongly disagree that "the harbour environment is generally healthy" but less likely to agree or strongly agree that "the harbour environment has been degraded by human development" (Fig. 2, Tables 3 and S7), relative to people in less modified locations. Contrary to our predictions, the people in countries with a higher cumulative impact index or locations with a higher percentage of modified harbour shoreline were less concerned about the harbour environment than the respondents in countries with a lower cumulative impact index or harbours with less modified shoreline (Fig 2, Tables 3 and S7). The proportion of respondents that were supportive of ecological engineering and agreed or strongly agreed to pay government taxes for ecological engineering projects and vote to ensure businesses included costs of ecological engineering in future developments increased with the percentage of harbour shoreline modified but was unrelated to the cumulative impact index (Tables 3 and S7). There were no clear relationships between a harbour's environmental status and people's willingness to donate money towards ecological engineering projects (Tables 3 and S7). 


\subsection{Relationships between connection to the harbour and location and individual perceptions}

Respondents' perceptions of the harbour environment and of ecological engineering varied within harbours, the latter according to the type and frequency of their harbour use (Figs. 3-4; Tables 4 and S8). Overall, the people who used the harbour for cultural activities, lesuire, paid and unpaid work and transport or lived on it (i.e. owned or rented property) had a significantly higher concern for the harbour environment and a greater perceived knowledge of the harbour environment relative to those who did not use the harbour for any activities or did not live alongside it (Fig. 3, Tables 4 and S8). Similarly, people who used the harbour for any activity, visited the harbour more than once per year, gained greater than $11 \%$ of their income from the harbour or lived near harbours for longer than 1 year had significantly greater concern for the harbour environment and a higher perceived knowledge of the harbour environment than people who did not use the harbour, used the harbour less frequently, derived $10 \%$ or less of their income from the harbour or lived near the harbour for less time (Fig. 3, Tables 4 and S8). People who used the harbour for any activity or gained greater than $11 \%$ of their income from the harbour were also more likely to vote to ensure businesses included the costs of ecological engineering in future developments (Tables 4 and S8). There were also significant but weak (small effect sizes) relationships between all measures of connectness (type of use, frequency of use, \% of income gained and number of years living near the harbour) and people's perceived knowledge of ecological engineering (Tables 4 and S8). Willingess to personally donate to ecological engineering projects or to pay government taxes towards ecological engineering projects displayed no relationship with connectedness to harbour (Table S8). In contrast, there was no clear relationship between 
type of harbour use, frequency of harbour use, the number of years living by a harbour, or percentage of income on support for ecological engineering (Tables 4 and S8).

\section{Discussion}

There is an increasing interest in understanding the factors that influence people's perceptions of urban environments to improve their social acceptance for conservation and management activities (Ambrosius and Gilderbloom, 2015; Berenguer et al., 2005; Janse and Konijnendijk, 2007; Priego et al., 2008; Van den Berg et al., 2007). This study, for the first time, assessed whether the factors that influence human perceptions of modified terrestrial ecosystems (Ambrosius and Gilderbloom, 2015; Priego et al., 2008; Van den Berg et al., 2007) apply to marine harbours. As predicted, we found that people's perception of world harbours as healthy or degraded reflected the degree to which they were impacted, but there was a negative relationship between the degree of impact and their concern for the harbour environment. Despite this, there was a positive relationship between the percentage of harbour waterway modified and the extent of support for ecological engineering and people's willingness to pay government taxes or vote to ensure businesses include ecological engineering initiatives in future developments (Kienker et al., 2018). At the individual level, all measures of connectedness to the environment were good predictors of concern for and knowledge about the harbour environment, and knowledge of ecological engineering but not support for or willingness to pay for ecological engineering.

Urban community perceptions of their environment can be influenced by differing cultural values and socio-economic characteristics (Madureira et al., 2015; Madureira et al., 2018; 
Priego et al., 2008). We found differences among locations in people's perception of the harbour environment and of ecological engineering. While people surveyed at the six Australasian and American harbours generally had high concern and average to good knowledge of the harbour environment (Kienker et al., 2018; Morris et al., 2016), people surveyed at the six European and Asian harbours reported only average concern for the environment and average knowledge of the environment. These differences could be attributed to the faster rates of harbour development, increasing population densities or habituation (decreasing concern after repeated exposure to impacted and degraded harbour environments) in the harbours that were surveyed in Europe and Asia as opposed to the harbours that were surveyed in Australasia and America (Madureira et al., 2015; Madureira et al., 2018; Pacione, 2003). Alternatively, these results could be linked to greater media attention and scientific interest in ecological engineering in Australia and America relative to other locations (Morris et al., 2018; Strain et al., 2018b). Active and publicly visible ecological engineering projects may make the public more aware of the plight of harbour environments and concerned for them. Greater understanding of the factors leading to these cultural differences in the perception of people toward the harbour environment will be critical in developing locally relevant management solutions.

Understanding how people's perceptions of ecological health and degradation correlate with reality is essential for developing robust and effective policy and management strategies (Jefferson et al., 2015; Scyphers et al., 2015). Where populations do not perceive the full severity of ecological damage, appropriate management strategies may not be developed or implemented, and ecosystems are at risk of further degradation (Burger, 2003; Druschke and Hychka, 2015; McManus, 2006). A disconnect between perception and reality may occur due to the shifting baseline phenomenon (McHarg and Mumford, 1969; Pauly, 1995) whereby 
changes in the state of the environment occur over time, but populations fail to record or remember by how much, resulting in changing perceptions by each generation of what is "natural".

Our twelve locations had very different histories of development (Steinberg et al. 2016). For example, the Port of Ravenna was developed by Roman Emperor Augustus (31 BC) (Airoldi et al., 2016), and the anthropogenic activities around Xiamen began in 282 AD (Zhang et al., In review). In contrast, European settlement of the Derwent Estuary in Hobart and Waitematā Harbour in Auckland (Augirre et al. 2012) date only to the late 1700s and early1800s, and extensive development of these locations commenced in the 1800s. Despite the differing histories of development in the twelve harbours, we found that the people perceptions of harbour health and degradation correlated strongly with actual harbour status, using each of two independent measures of degradation - the cumulative impact index and the percent of harbour waterway that is modified. In contrast, we found greater concern for harbour environments among the relatively less developed and degraded harbours (e.g. Hobart and Auckland), than the more developed and degraded harbours (e.g. Ravenna and Xiamen). This finding could be a result of the shifting baseline syndrome (sensu Pauly 1995), where people living in degraded systems have lower expectations or perceptions of a healthy ecosystem. Interestingly, despite the relatively coarse level of information about impacts provided by the cumulative impact index (country level, with 10 harbours classified as less impacted), largely concordant results were produced independent of whether percentage of harbour waterway modification or cumulative impact index was used as the metric of degradation. 
Assessing the relationship between people and place is important for predicting how various stakeholders will rate their concern for the harbour environment and support for conservation (Jefferson et al., 2015; Wyles et al., 2014). In this study, we found various measures of connectedness (frequency of use, type of activities, percentage of income and number of years living near the harbour) were positively correlated with the people's concern and perceived knowledge about the harbour environment. These results are not surprising given that long-term residents tend to have a stronger connection with place as local knowledge increases, and social networks and community ties strengthen over time (Hay, 1998; Kelly and Hosking, 2008). Contact with nature has also been found to be beneficial to both people's physical and mental health (Capaldi et al., 2014; Nisbet and Zelenski, 2011) and can result in pro-environmental behaviour (Beery and Wolf-Watz, 2014; Nisbet et al., 2009).

As in other studies, there was a very high support (>88\%) and willingness to pay indirectly (i.e. government taxes and mandate) for the costs of ecological engineering, across most locations (Evans et al., 2017; Kienker et al., 2018; Morris et al., 2016). In contrast, there were only weak relationships between connectedness to the harbour environment and the people's knowledge of ecological engineering and willingness to vote to ensure business included the costs of ecological engineering in future developments. This may be because ecological engineering in the coastal realm is a relatively new discipline (Borsje et al., 2011; Chapman and Underwood, 2011; Mitsch, 2012) and there are many forms of ecological engineering which are not visible (e.g. subtidally constructed mussel or oyster reefs) or accessible to the public (e.g. ecological habitat enhancements of seawalls). These results highlight the need to provide accessible examples of ecological engineering projects (e.g. Barangaroo https://www.barangaroo.com/) to increase awareness and knowledge about the benefits of these management strategies for the harbour environment (Kabisch et al., 2016). 
In this study, we combined two types of non-probabilistic sampling - purposive and convenience, to provide crucial insights into what people think about their harbour environment, and ecological engineering. This type of sampling was used to provide large scale and cost-effective observations, that can be difficult to achieve with other methods (Brown and Weber, 2012; Jarvis et al., 2015). We compared the data collected via the survey to equivalent census information at city or country level. Across the twelve locations, we found the proportion of males and females (excluding Plymouth and Santander) and their average individual income per year (excluding Penang, Keelung and Xiamen) did not differ from census information but the percentage of highly educated people with a university degree, and the age groups of 18-34 and 35-54 were overrepresented relative to the census data. These biases may be due to several reasons, such as the online administration of the survey, the survey's non-inclusion of people under 18 years and a greater interest in the subject by more educated people. Alternatively, there could be fundamental differences in the socio-economic characteristics of harbour users relative to city or country populations. Further study with greater social diversity and using a range of methods is required to distinguish between these possibilities. Irrespective, our results provide important insights into some of key harbour and individual level factors which influence the people's perceptions of harbour environments and ecological engineering.

\subsection{Recommendations}

Overall, we revealed that most urban people generally have a good understanding of the condition of the harbour environment and are supportive of the multiple potential benefits 
offered by local ecological engineering initiatives for marine artificial structures (Evans et al., 2017; Kienker et al., 2018; Morris et al., 2016). However, the main challenge identified by the survey is a need to empower the public with the knowledge necessary to make more informed decisions about management and policy options for urban harbours (Gelcich et al., 2014), as a high proportion of people within each harbour rated their knowledge of ecological engineering as poor or very poor. This was particularly important in the harbours we surveyed in Europe and Asia, which had high levels of degradation, a high percentage of modification by artificial structures, but only average concern about the harbour environment.

Low levels of knowledge regarding local ecological engineering interventions may be addressed through greater stakeholder consultation in development and management plans, open meetings (e.g. http://www.rebuildbydesign.org/our-work/all-proposals/winningprojects/ny-living-breakwaters) and highly visible and accessible projects that showcase environmental management strategies to the public (Kabisch et al., 2016). These projects may also achieve greater public acceptance by more firmly embedding environmental education in school and university curricula (Palmer, 2002), providing financial incentives for uptake (Scyphers et al., 2015; Sutton-Grier et al., 2018), and developing standardised monitoring tools to engage with citizen scientists (Toft et al., 2017).

Additionally, because connection (either living alongside or regular user) to harbours was a key predictor of an individual's concern for, and perceived knowledge about, the harbour environment, programs that foster people to be active in their harbour area, may effective at increasing environmental awareness (Schultz, 2011). The increasing interest in large-scale urban renewal projects that remove physical barriers between people and waterways by reinstating foreshore environments could also help to rebuild their connectedness to harbour 
environments (Chan and Lee, 2008; Liu et al., 2018). Community engagement initiatives such as foreshore cleaning events or volunteer service days could also help to rebuild these connections. It is imperative that waterfront projects integrate ecological and socio-economic perspectives into the planning process to achieve true success across multiple stakeholder groups (Sairinen and Kumpulainen, 2006; Yepsen et al., 2016).

\section{Acknowledgements}

We thank The Ian Potter Foundation (Grant no: NA), the Harding Miller Foundation (Grant no: NA), the New South Wales Government Office of Science and Research, Research Coastal Node of the NSW Office of Environment and Heritage Adaptation Hub (Grant no: NA), Northeastern University (Grant no: NA), Rufford Small Grants (Grant no: 304.PPANTAI.650876.T128), E\&O Properties Penang Sdn. Bhd. (Grant no: 304.PPANTAI.650827.E118), and the RUI grant (Grant no: 1001.PPANTAI.811341) for their financial support. Special thanks for help with collecting survey responses, to Dominic McAfee and Stephanie Bagala in Sydney, Alicia Donnellan Barraclough in Auckland, the students and staff of the Scypher and Grabowski laboratories in Boston and Marco Abbiati, Massimo Ponti, Marina Colangelo and Francesca Costantini in Ravenna. This study was part of the World Harbour Project (http://www.worldharbourproject.org/).

\section{References}

Aguirre JD, Bollard-Breen B, Cameron M, Constantine R, Duffy CA, Dunphy B, et al. Loved to pieces: Toward the sustainable management of the Waitematā Harbour and Hauraki Gulf. Regional Studies in Marine Science 2016; 8: 220-233. 
Airoldi L, Beck MW. Loss, status and trends for coastal marine habitats of Europe.

Oceanography and Marine Biology. CRC Press, 2007, pp. 357-417.

Airoldi L, Ponti M, Abbiati M. Conservation challenges in human dominated seascapes: The harbour and coast of Ravenna. Regional Studies in Marine Science 2016; 8: 308-318.

Ambrosius JD, Gilderbloom JI. Who's greener? Comparing urban and suburban residents' environmental behaviour and concern. Local Environment 2015; 20: 836-849.

Atkins JP, Burdon D, Allen JH. An application of contingent valuation and decision tree analysis to water quality improvements. Marine Pollution Bulletin 2007; 55: 591-602.

Ban NC, Mills M, Tam J, Hicks CC, Klain S, Stoeckl N, et al. A social-ecological approach to conservation planning: embedding social considerations. Frontiers in Ecology and the Environment 2013; 11: 194-202.

Ban NC, Picard CR, Vincent AC. Comparing and integrating community- based and science- based approaches to prioritizing marine areas for protection. Conservation Biology 2009; 23: 899-910.

Beery TH, Wolf-Watz D. Nature to place: Rethinking the environmental connectedness perspective. Journal of Environmental Psychology 2014; 40: 198-205.

Berenguer J, Corraliza JA, Martín R. Rural-Urban Differences in Environmental Concern, Attitudes, and Actions. European Journal of Psychological Assessment 2005; 21: 128. Blair J, Czaja RF, Blair EA. Designing surveys: A guide to decisions and procedures. Los Angles, USA: Sage Publications, 2013.

Borsje BW, van Wesenbeeck BK, Dekker F, Paalvast P, Bouma TJ, van Katwijk MM, et al. How ecological engineering can serve in coastal protection. Ecological Engineering 2011; 37: 113-122.

Brown G, Kyttä M. Key issues and research priorities for public participation GIS (PPGIS): A synthesis based on empirical research. Applied Geography 2014; 46: 122-136. 
Brown G, Weber D. Measuring change in place values using public participation GIS (PPGIS). Applied Geography 2012; 34: 316-324.

Burger J. Assessing perceptions about ecosystem health and restoration options in three east coast estuaries. Environmental Monitoring and Assessment 2003; 83: 145-162.

Capaldi CA, Dopko RL, Zelenski JM. The relationship between nature connectedness and happiness: a meta-analysis. Frontiers in Psychology 2014; 5: 976.

Chan E, Lee GK. Critical factors for improving social sustainability of urban renewal projects. Social Indicators Research 2008; 85: 243-256.

Chapman M, Underwood A. Evaluation of ecological engineering of "armoured" shorelines to improve their value as habitat. Journal of Experimental Marine Biology and Ecology 2011; 400: 302-313.

Chee SY, Othman AG, Sim YK, Adam ANM, Firth LB. Land reclamation and artificial islands: Walking the tightrope between development and conservation. Global Ecology and Conservation 2017; 12: 80-95.

Cormier R, Elliott M. SMART marine goals, targets and management-Is SDG 14 operational or aspirational, is 'Life Below Water'sinking or swimming? Marine pollution bulletin 2017; 123: 28-33.

Crain CM, Halpern BS, Beck MW, Kappel CV. Understanding and managing human threats to the coastal marine environment. Annals of the New York Academy of Sciences 2009; 1162: 39-62.

Derkzen ML, van Teeffelen AJ, Verburg PH. Green infrastructure for urban climate adaptation: How do residents' views on climate impacts and green infrastructure shape adaptation preferences? Landscape and Urban Planning 2017; 157: 106-130.

Druschke CG, Hychka KC. Manager perspectives on communication and public engagement in ecological restoration project success. Ecology and Society 2015; 20. 
Easman ES, Abernethy KE, Godley BJ. Assessing public awareness of marine environmental threats and conservation efforts. Marine Policy 2018; 87: 234-240.

Elliott M. The 10-tenets for integrated, successful and sustainable marine management. Marine pollution bulletin 2013; 1: 1-5.

Evans AJ, Garrod B, Firth LB, Hawkins SJ, Morris-Webb ES, Goudge H, et al. Stakeholder priorities for multi-functional coastal defence developments and steps to effective implementation. Marine Policy 2017; 75: 143-155.

Firth LB, Knights AM, Bridger D, Evans A, Mieskowska N, Moore PJ, et al. Ocean sprawl: challenges and opportunities for biodiversity management in a changing world. Oceanography and Marine Biology:. 54. CRC Press, 2016, pp. 201-278.

Fransson N, Gärling T. Environmental concern: Conceptual definitions, measurement methods, and research findings. Journal of Environmental Psychology 1999; 19: 369382.

Franzen A, Meyer R. Environmental attitudes in cross-national perspective: A multilevel analysis of the ISSP 1993 and 2000. European Sociological Review 2009; 26: 219234.

Gelcich S, Buckley P, Pinnegar JK, Chilvers J, Lorenzoni I, Terry G, et al. Public awareness, concerns, and priorities about anthropogenic impacts on marine environments. Proceedings of the National Academy of Sciences 2014; 111: 15042-15047.

Ghermandi A, Nunes PA. A global map of coastal recreation values: Results from a spatially explicit meta-analysis. Ecological Economics 2013; 86: 1-15.

Gifford R, Nilsson A. Personal and social factors that influence pro- environmental concern and behaviour: A review. International Journal of Psychology 2014; 49: 141-157. 
Gray JDE, O'Neill K, Qiu Z. Coastal residents' perceptions of the function of and relationship between engineered and natural infrastructure for coastal hazard mitigation. Ocean and Coastal Management 2017; 146: 144-156.

Gunderson K. Understanding place meanings for wilderness: personal and community values at risk. International Journal of Wilderness. Vol. 12 (1): 27-31. 2006.

Halpern BS, Walbridge S, Selkoe KA, Kappel CV, Micheli F, D'agrosa C, et al. A global map of human impact on marine ecosystems. Science 2008; 319: 948-952.

Harris PA, Taylor R, Thielke R, Payne J, Gonzalez N, Conde JG. A metadata-driven methodology and workflow process for providing translational research informatics support. J Biomed Inform 2009; 42: 377-81.

Hay R. Sense of place in developmental context. Journal of Environmental Psychology 1998; 18: 5-29.

Heery EC, Bishop MJ, Critchley LP, Bugnot AB, Airoldi L, Mayer-Pinto M, et al. Identifying the consequences of ocean sprawl for sedimentary habitats. Journal of Experimental Marine Biology and Ecology 2017; 492: 31-48.

Janse G, Konijnendijk CC. Communication between science, policy and citizens in public participation in urban forestry_Experiences from the Neighbourwoods project. Urban Forestry and Urban Greening 2007; 6: 23-40.

Jarvis RM, Breen BB, Krägeloh CU, Billington DR. Citizen science and the power of public participation in marine spatial planning. Marine Policy 2015; 57: 21-26.

Jarvis RM, Breen BB, Krägeloh CU, Billington DR. Identifying diverse conservation values for place-based spatial planning using crowdsourced voluntary geographic information. Society and Natural Resources 2016; 29: 603-616. 
Jefferson R, McKinley E, Capstick S, Fletcher S, Griffin H, Milanese M. Understanding audiences: making public perceptions research matter to marine conservation. Ocean and Coastal Management 2015; 115: 61-70.

Kabisch N, Frantzeskaki N, Pauleit S, Naumann S, Davis M, Artmann M, et al. Nature-based solutions to climate change mitigation and adaptation in urban areas: perspectives on indicators, knowledge gaps, barriers, and opportunities for action. Ecology and Society $2016 ; 21$.

Kelly G, Hosking K. Nonpermanent residents, place attachment, and "sea change" communities. Environment and Behavior 2008; 40: 575-594.

Kemper EA, Stringfield S, Teddlie C. Mixed methods sampling strategies in social science research. In: Tashakkori A, Teddlie C, editors. Mixed methods sampling strategies in social science research. 2. Sage, Los Angles, USA, 2003, pp. 273-296.

Kienker S, Coleman R, Morris R, Steinberg P, Bollard B, Jarvis R, et al. Bringing harbours alive: Assessing the importance of eco-engineered coastal infrastructure for different stakeholders and cities. Marine Policy 2018; 94: 238-246.

Kleiber C, Zeileis A. Applied Econometrics with R. Springer-Verlag, New York, 2008.

Knights AM, Firth LB, Thompson RC, Yunnie AL, Hiscock K, Hawkins SJ. Plymouth—a world harbour through the ages. Regional Studies in Marine Science 2016; 8: 297 307.

Lai S, Loke LH, Hilton MJ, Bouma TJ, Todd PA. The effects of urbanisation on coastal habitats and the potential for ecological engineering: A Singapore case study. Ocean and Coastal Management 2015; 103: 78-85.

Liere KDV, Dunlap RE. The social bases of environmental concern: A review of hypotheses, explanations and empirical evidence. Public Opinion Quarterly 1980; 44: 181-197. 
Liu B, Wang X, Xia N, Ni W. Critical Success Factors for the Management of Public Participation in Urban Renewal Projects: Perspectives from Governments and the Public in China. Journal of Urban Planning and Development 2018; 144: 04018026.

Lotze HK, Lenihan HS, Bourque BJ, Bradbury RH, Cooke RG, Kay MC, et al. Depletion, degradation, and recovery potential of estuaries and coastal seas. Science 2006; 312: 1806-1809.

Madureira H, Nunes F, Oliveira JV, Cormier L, Madureira T. Urban residents' beliefs concerning green space benefits in four cities in France and Portugal. Urban Forestry and Urban Greening 2015; 14: 56-64.

Madureira H, Nunes F, Oliveira JV, Madureira T. Preferences for Urban Green Space Characteristics: A Comparative Study in Three Portuguese Cities. Environments 2018; 5: 23.

McCool SF, Martin SR. Community attachment and attitudes toward tourism development. Journal of Travel Research 1994; 32: 29-34.

McGranahan G, Balk D, Anderson B. The rising tide: assessing the risks of climate change and human settlements in low elevation coastal zones. Environment and Urbanization 2007; 19: 17-37.

McHarg IL, Mumford L. Design with nature: American Museum of Natural History New York, 1969.

McManus P. Mangrove battlelines: culture/nature and ecological restoration. Australian Geographer 2006; 37: 57-71.

Menz MH, Dixon KW, Hobbs RJ. Hurdles and opportunities for landscape-scale restoration. Science 2013; 339: 526-527.

Mitsch WJ. What is ecological engineering? Ecological Engineering 2012; 45: 5-12. 
Morris RL, Deavin G, Hemelryk Donald S, Coleman RA. Eco- engineering in urbanised coastal systems: consideration of social values. Ecological Management and Restoration 2016; 17: 33-39.

Morris RL, Konlechner TM, Ghisalberti M, Swearer SE. From grey to green: Efficacy of eco- engineering solutions for nature- based coastal defence. Global Change Biology 2018; 24: 1827-1842.

Nisbet EK, Zelenski JM. Underestimating nearby nature: Affective forecasting errors obscure the happy path to sustainability. Psychological science 2011;22: 1101-1106.

Nisbet EK, Zelenski JM, Murphy SA. The nature relatedness scale: Linking individuals' connection with nature to environmental concern and behavior. Environment and Behavior 2009; 41: 715-740.

Pacione M. Urban environmental quality and human wellbeing — a social geographical perspective. Landscape and urban planning 2003; 65: 19-30.

Palmer JA. Environmental education in the 21st century: Theory, practice, progress and promise: Routledge, 2002.

Pauly D. Anecdotes and the shifting baseline syndrome of fisheries. Trends in Ecology and Evolution 1995; 10: 430.

Pearson S, Windupranata W, Pranowo SW, Putri A, Ma Y, Vila-Concejo A, et al. Conflicts in some of the World harbours: what needs to happen next? Maritime Studies 2016; 15 : 10.

Priego C, Breuste J, Rojas J. Perception and value of nature in urban landscapes: a comparative analysis of cities in Germany, Chile and Spain. Landscape Online 2008; 7: 22 . 
Prosser DJ, Jordan TE, Nagel JL, Seitz RD, Weller DE, Whigham DF. Impacts of coastal land use and shoreline armoring on estuarine ecosystems: an introduction to a special issue. Estuaries and Coasts 2017: 1-17.

R Development Core Team. R: A language and environment for statistical computing. $\mathrm{R}$ Foundation for Statistical Computing, , Vienna, Austria, 2018.

Raymond CM, Brown G, Weber D. The measurement of place attachment: Personal, community, and environmental connections. Journal of Environmental Psychology 2010; 30: 422-434.

Reed MS. Stakeholder participation for environmental management: a literature review. Biological Conservation 2008; 141: 2417-2431.

Roca E, Villares M. Public perceptions for evaluating beach quality in urban and semi-natural environments. Ocean and Coastal Management 2008; 51: 314-329.

Sairinen R, Kumpulainen S. Assessing social impacts in urban waterfront regeneration. Environmental impact assessment review 2006; 26: 120-135.

Scyphers SB, Picou JS, Powers SP. Participatory conservation of coastal habitats: the importance of understanding homeowner decision making to mitigate cascading shoreline degradation. Conservation Letters 2015; 8: 41-49.

Small C, Nicholls RJ. A global analysis of human settlement in coastal zones. Journal of Coastal Research 2003: 584-599.

Smith CS, Gittman RK, Neylan IP, Scyphers SB, Morton JP, Fodrie FJ, et al. Hurricane damage along natural and hardened estuarine shorelines: Using homeowner experiences to promote nature-based coastal protection. Marine Policy 2017; 81: 350358.

Steinberg PD, Airoldi L, Banks J, Leung KM. Introduction to the special issue on the World Harbour Project. Regional Studies in Marine Science 2016; 8: 217-219. 
Strain E, Morris RL, Bishop MJ, Tanner E, Steinberg P, Swearer SE, et al. Building blue infrastructure: Assessing the key environmental issues and priority areas for ecological engineering initiatives in Australia's metropolitan embayments. Journal of Environmental Management 2018a; online first.

Strain E, Olabarria C, Mayer- Pinto M, Cumbo V, Morris RL, Bugnot AB, et al. Eco- engineering urban infrastructure for marine and coastal biodiversity: which interventions have the greatest ecological benefit? Journal of Applied Ecology 2018b; 55: 426-441.

Sutton-Grier AE, Gittman RK, Arkema KK, Bennett RO, Benoit J, Blitch S, et al. Investing in natural and nature-based infrastructure: building better along our coasts. Sustainability 2018; 10: 523.

Toft J, Fore L, Hass T, Bennett B, Brubaker L, Brubaker D, et al. A Framework to Analyze Citizen Science Data for Volunteers, Managers, and Scientists. Citizen Science: Theory and Practice 2017; 2.

Van den Berg AE, Hartig T, Staats H. Preference for nature in urbanized societies: Stress, restoration, and the pursuit of sustainability. Journal of Social Issues 2007; 63: 79-96.

Wyles KJ, Pahl S, Thompson RC. Perceived risks and benefits of recreational visits to the marine environment: Integrating impacts on the environment and impacts on the visitor. Ocean \& Coastal Management 2014; 88: 53-63.

Yepsen M, Moody J, Schuster E. A Framework for developing monitoring plans for coastal wetland restoration and living shoreline projects in New Jersey. Report prepared by the New Jersey Measures and Monitoring Workgroup of the NJ Resilient Coastlines Initiative, with support from the NOAA National Oceanic and Atmospheric Administration (NOAA) Coastal Resilience (CRest) Grant program (NA14NOS4830006) 2016. 
Zhang L, Xiaofang WU, Yunwei D. Planning towards sustainability of Xiamen Harbor in China. Regional Studies in Marine Science In review. 
Table 1 Socio-economic characteristics of respondent's and their understanding of the survey questions in each location. Categories with the highest percentage of respondents are indicated in bold print and categories which are significantly different from the census population are indicated $* \mathrm{p}>0.05$ and - indicates census data is not available.

\begin{tabular}{|c|c|c|c|c|c|c|c|c|c|c|c|c|c|}
\hline \multirow{2}{*}{$\begin{array}{l}\text { Region } \\
\text { Variables }\end{array}$} & & \multicolumn{4}{|c|}{ Australasia } & \multicolumn{2}{|l|}{ America } & \multicolumn{3}{|c|}{ Europe } & \multicolumn{3}{|l|}{ Asia } \\
\hline & & Sydney & Melbourne & Hobart & Auckland & Arraial do Cabo & Boston & Plymouth & Ravenna & Santander & Keelung & Penang & Xiamen \\
\hline Gender & $\begin{array}{l}\text { Females (\%) } \\
\text { Males }(\%) \\
\text { Other }(\%) \\
\end{array}$ & $\begin{array}{l}\mathbf{5 2 . 1} \\
47.9 \\
0 \\
\end{array}$ & $\begin{array}{l}\mathbf{5 1 . 6} \\
48.4 \\
0 \\
\end{array}$ & $\begin{array}{l}\mathbf{5 0 . 4} \\
48.3 \\
1.3 \\
\end{array}$ & $\begin{array}{l}47.8 \\
\mathbf{5 2 . 2} \\
0 \\
\end{array}$ & $\begin{array}{l}48.3 \\
\mathbf{5 1 . 7} \\
0.56 \\
\end{array}$ & $\begin{array}{l}\mathbf{5 6 . 0} \\
44.0 \\
0 \\
\end{array}$ & $\begin{array}{l}41.2 \\
\mathbf{5 8 . 9 *} \\
0\end{array}$ & $\begin{array}{l}46.4 \\
\mathbf{5 0 . 6} \\
0.6 \\
\end{array}$ & $\begin{array}{l}42.1 \\
\mathbf{5 8 . 0 *} \\
0 \\
\end{array}$ & $\begin{array}{l}\mathbf{5 6 . 7} \\
43.3 \\
0 \\
\end{array}$ & $\begin{array}{l}\mathbf{5 7 . 1} \\
43.0 \\
0.6 \\
\end{array}$ & $\begin{array}{l}44.3 \\
\mathbf{5 5 . 7} \\
0.6 \\
\end{array}$ \\
\hline Age & $\begin{array}{l}18-34(\%) \\
35-54(\%) \\
55-73(\%) \\
74-95(\%)\end{array}$ & $\begin{array}{l}39.2 * \\
38.7 \\
21.7 \\
0.5^{*} \\
\end{array}$ & $\begin{array}{l}23.6 \\
\mathbf{4 8 . 4} * \\
24.2 \\
3.8^{*} \\
\end{array}$ & $\begin{array}{l}25.0 \\
\mathbf{4 7 . 4} * \\
25.4 \\
2.2 \\
\end{array}$ & $\begin{array}{l}\mathbf{4 7 . 3 *} \\
30.0^{*} \\
21.7 \\
1.1 \\
\end{array}$ & $\begin{array}{l}\mathbf{5 0 . 3} * \\
37.5^{*} \\
11.7 \\
0.6 \\
\end{array}$ & $\begin{array}{l}\text { 61.2* } \\
16.6^{*} \\
21.7^{*} \\
0.6^{*} \\
\end{array}$ & $\begin{array}{l}\mathbf{4 7 . 5 *} \\
32.0 \\
19.4 \\
1.2 \\
\end{array}$ & $\begin{array}{l}49.7 * \\
40.1 * \\
10.2 * \\
0 * \\
\end{array}$ & $\begin{array}{l}\mathbf{4 4 . 3} * \\
\mathbf{4 4 . 3} \\
10.8 \\
0.6 \\
\end{array}$ & $\begin{array}{l}\mathbf{6 3 . 3} * \\
34.1^{*} \\
2.4^{*} \\
0.3^{*} \\
\end{array}$ & $\begin{array}{l}\text { 64.3* } \\
26.0 \\
9.7 \\
0 * \\
\end{array}$ & $\begin{array}{l}89.9 * \\
10.1 \\
0 * \\
0 * \\
\end{array}$ \\
\hline Education & $\begin{array}{l}\text { School } \\
\text { College/TAFE } \\
\text { diploma } \\
\text { Bachelor } \\
\text { Postgrad } \\
\end{array}$ & $\begin{array}{l}7.0 * \\
14.8 \\
\\
38.7 * \\
39.7 * \\
\end{array}$ & $\begin{array}{l}4.5^{*} \\
14.0 \\
\\
34.4^{*} \\
\mathbf{4 7 . 1} * \\
\end{array}$ & $\begin{array}{c}5.6^{*} \\
19.4 \\
\\
32.3^{*} \\
\mathbf{4 2 . 7}^{*} \\
\end{array}$ & $\begin{array}{l}13.9 * \\
12.8 \\
\\
32.8 \\
\mathbf{4 0 . 5} * \\
\end{array}$ & $\begin{array}{l}21.2^{*} \\
8.3- \\
21.2 * \\
49.1 * \\
\end{array}$ & $\begin{array}{l}26.9 \\
6.9 \\
29.2 \\
\mathbf{3 7 . 2} * \\
\end{array}$ & $\begin{array}{l}8.6 \\
29.1- \\
\\
29.7^{*} \\
\text { 32.6* } \\
\end{array}$ & $\begin{array}{l}22.2 * \\
\text { NA } \\
27.0 * \\
50.9 * \\
\end{array}$ & $\begin{array}{l}11.4^{*} \\
5.1- \\
26.7 * \\
67.0 * \\
\end{array}$ & $\begin{array}{l}0.5^{*} \\
9.7- \\
\\
\mathbf{5 2 . 4} \\
37.3^{*} \\
\end{array}$ & $\begin{array}{l}4.9 * \\
16.8- \\
60.0 * \\
18.3 * \\
\end{array}$ & $\begin{array}{l}2.38^{*} \\
2.38- \\
\\
\mathbf{5 7 . 7 4}^{*} \\
37.50^{*} \\
\end{array}$ \\
\hline Annual income & $\begin{array}{l}\text { Very low }(\%) \\
\text { Low }(\%) \\
\text { Average }(\%) \\
\text { High }(\%) \\
\text { Very high }(\%)\end{array}$ & $\begin{array}{l}18.0- \\
16.6- \\
22.6 \\
\text { 30.0- } \\
12.9- \\
\end{array}$ & $\begin{array}{l}25.5- \\
12.8- \\
16.5 \\
31.2- \\
14.0- \\
\end{array}$ & $\begin{array}{l}32.9- \\
13.4- \\
16.9 \\
26.0- \\
10.8- \\
\end{array}$ & $\begin{array}{l}35.8- \\
20.1- \\
15.1 \\
20.7- \\
8.4- \\
\end{array}$ & $\begin{array}{l}\text { 26.8- } \\
11.8- \\
16.2 \\
23.5- \\
21.8- \\
\end{array}$ & $\begin{array}{l}\text { 42.3- } \\
12.0- \\
11.5- \\
14.3- \\
20.0-\end{array}$ & $\begin{array}{l}21.7- \\
24.0- \\
\mathbf{2 5 . 2 -} \\
20.0- \\
9.1-\end{array}$ & $\begin{array}{l}\text { 31.8- } \\
21.0- \\
7.2- \\
9.6- \\
15.0- \\
\end{array}$ & $\begin{array}{l}16.5- \\
22.7- \\
34.7 \\
13.7- \\
12.5- \\
\end{array}$ & $\begin{array}{l}\mathbf{5 4 . 4 -} \\
8.7- \\
17.6^{*} \\
10.3- \\
9.2- \\
\end{array}$ & $\begin{array}{l}\mathbf{5 4 . 6 -} \\
15.7- \\
21.1 * \\
7.1- \\
1.6-\end{array}$ & $\begin{array}{l}\text { 61.3- } \\
11.3- \\
10.7 * \\
10.7- \\
6.0- \\
\end{array}$ \\
\hline $\begin{array}{l}\text { People who } \\
\text { answered the } \\
\text { survey in their } \\
\text { native language }\end{array}$ & $(\%)$ & 90.8 & 96.2 & 100.0 & 86.1 & 99.5 & 92.0 & 100.0 & 98.2 & 96.6 & 80.3 & 73.0 & 74.4 \\
\hline $\begin{array}{l}\text { Understanding of } \\
\text { the survey }\end{array}$ & Majority & Good & Very good & Good & Good & Good & Good & Average & Good & Good & Average & Good & Average \\
\hline
\end{tabular}


Table 2: Differences among locations in people's concern for the harbour environment (none, low, average, moderate, high), perceived knowledge about the harbour environment (very poor, poor, average, good, very good), support for ecological engineering (answered yes) and perceived knowledge of ecological engineering (very poor, poor, average, good, very good), willingness to donate money for ecological engineering projects, pay taxes for ecological engineering projects and mandate for including ecological engineering in future projects (strongly disagree, disagree, neutral, agree, strongly agree), type of harbour use (I don't use the harbour, culture, leisure, property, paid or unpaid work); frequency of harbour use (I don't use the harbour, $<1$ visit per year, 4-6 months, 2-3 months, monthly, weekly, daily, I live here), income from the harbour (none, unknown, <10\%, 11-20\%, 21-50\%, 51-80\%, >81\%), number of years living by the harbour (I don't live here or 0 years, $<1$ year, 1-2 years, 3-5 years, 6-10 years, 11-15 years, 16-20 years, >21 years). The category with the highest proportion of responses is reported for each location.

\begin{tabular}{|c|c|c|c|c|c|c|c|c|c|c|c|c|}
\hline Region & Australasia & & & 28 & America & & Europe & & & Asia & & \\
\hline & Sydney & $\begin{array}{l}\text { Melbourn } \\
\text { e }\end{array}$ & Hobart & Auckland & Arraial do Cabo & Boston & $\begin{array}{l}\text { Plymout } \\
\text { h }\end{array}$ & $\begin{array}{l}\text { Ravenn } \\
\text { a }\end{array}$ & $\begin{array}{l}\text { Santande } \\
\mathbf{r}\end{array}$ & $\begin{array}{l}\text { Keelun } \\
\mathrm{g}\end{array}$ & Penang & Xiamen \\
\hline $\begin{array}{l}\text { Concern for } \\
\text { the } \\
\text { environmen }\end{array}$ & High (0.45) & $\begin{array}{l}\text { High } \\
(0.68)\end{array}$ & High (0.43) & High (0.47) & High (0.65) & $\begin{array}{l}\text { High } \\
(0.44)\end{array}$ & $\begin{array}{l}\text { Average } \\
(0.32)\end{array}$ & $\begin{array}{l}\text { Moderat } \\
\text { e- } \\
\text { Average }\end{array}$ & $\begin{array}{l}\text { Average } \\
(0.52)\end{array}$ & $\begin{array}{l}\text { Averag } \\
\text { e (0.47) }\end{array}$ & $\begin{array}{l}\text { Moderat } \\
\text { e (0.45) }\end{array}$ & $\begin{array}{l}\text { Average } \\
(0.47)\end{array}$ \\
\hline $\begin{array}{l}\text { Perceived } \\
\text { knowledge } \\
\text { about the } \\
\text { environmen } \\
\text { t }\end{array}$ & Average $(0.42)$ & $\begin{array}{l}\text { Good } \\
(0.44)\end{array}$ & $\begin{array}{l}\text { Average } \\
(0.32)\end{array}$ & $\begin{array}{l}\text { Average-Good } \\
(0.32)\end{array}$ & $\overline{\text { Good }(0.33)}$ & $\begin{array}{l}\text { Average } \\
\text {-Good } \\
(0.26)\end{array}$ & $\begin{array}{l}\text { Average } \\
(0.33)\end{array}$ & $\begin{array}{l}\text { Average } \\
(0.34)\end{array}$ & $\begin{array}{l}\text { Average } \\
(0.47)\end{array}$ & $\begin{array}{l}\text { Averag } \\
\text { e (0.52) }\end{array}$ & $\begin{array}{l}\text { Average } \\
(0.54)\end{array}$ & $\begin{array}{l}\text { Average } \\
(0.44)\end{array}$ \\
\hline $\begin{array}{l}\text { Support for } \\
\text { ecological } \\
\text { engineering }\end{array}$ & Yes $(0.95)$ & Yes $(0.95)$ & Yes $(0.91)$ & Yes (0.94) & Yes $(0.97)$ & $\begin{array}{l}\text { Yes } \\
(0.98)\end{array}$ & $\begin{array}{l}\text { Yes } \\
(0.88)\end{array}$ & $\begin{array}{l}\text { Yes } \\
(0.95)\end{array}$ & $\begin{array}{l}\text { Yes } \\
(0.90)\end{array}$ & $\begin{array}{l}\text { Yes } \\
(0.99)\end{array}$ & $\begin{array}{l}\text { Yes } \\
(0.95)\end{array}$ & $\begin{array}{l}\text { Yes } \\
(0.98)\end{array}$ \\
\hline $\begin{array}{l}\text { Perceived } \\
\text { knowledge } \\
\text { of } \\
\text { ecological }\end{array}$ & Poor $(0.35)$ & $\begin{array}{l}\text { Poor } \\
(0.32)\end{array}$ & Poor $(0.33)$ & Poor (0.39) & Very poor $(0.37)$ & $\begin{array}{l}\text { Average } \\
(0.40)\end{array}$ & $\begin{array}{l}\text { Poor } \\
(0.35)\end{array}$ & $\begin{array}{l}\text { Poor } \\
(0.38)\end{array}$ & $\begin{array}{l}\text { Average } \\
(0.33)\end{array}$ & $\begin{array}{l}\text { Averag } \\
\text { e (0.46) }\end{array}$ & $\begin{array}{l}\text { Average } \\
(0.48)\end{array}$ & $\begin{array}{l}\text { Poor } \\
(0.37)\end{array}$ \\
\hline
\end{tabular}


ACCEPTED MANUSCRIPT

\begin{tabular}{|c|c|c|c|c|c|c|c|c|c|c|c|c|}
\hline engineering & & & & & & & & & & & & \\
\hline $\begin{array}{l}\text { Donate } \\
\text { money for } \\
\text { ecological } \\
\text { engineering } \\
\text { projects }\end{array}$ & Disagree (0.32) & $\begin{array}{l}\text { Neutral } \\
(0.33)\end{array}$ & $\begin{array}{l}\text { Disagree- } \\
\text { Neutral (0.33) }\end{array}$ & $\begin{array}{l}\text { Disagree- } \\
\text { Neutral }(0.35)\end{array}$ & $\begin{array}{l}\text { Disagree- } \\
\text { Neutral (0.28) }\end{array}$ & $\begin{array}{l}\text { Neutral- } \\
\text { Agree } \\
(0.38)\end{array}$ & $\begin{array}{l}\text { Neutral } \\
(0.39)\end{array}$ & $\begin{array}{l}\text { Disagree } \\
\text { - Neutral } \\
(0.34)\end{array}$ & $\begin{array}{l}\text { Neutral } \\
(0.35)\end{array}$ & $\begin{array}{l}\text { Neutral } \\
(0.45)\end{array}$ & $\begin{array}{l}\text { Neutral- } \\
\text { Agree } \\
(0.38)\end{array}$ & $\begin{array}{l}\text { Agree } \\
(0.37)\end{array}$ \\
\hline $\begin{array}{l}\text { Pay taxes } \\
\text { for } \\
\text { ecological } \\
\text { engineering } \\
\text { projects }\end{array}$ & Agree $(0.47)$ & $\begin{array}{l}\text { Agree } \\
(0.42)\end{array}$ & Agree $(0.40)$ & Agree $(0.42)$ & Disagree $(0.40)$ & $\begin{array}{l}\text { Agree } \\
(0.52)\end{array}$ & $\begin{array}{l}\text { Neutral } \\
(0.38)\end{array}$ & $\begin{array}{l}\text { Agree- } \\
\text { Disagree } \\
(0.31)\end{array}$ & $\begin{array}{l}\text { Agree } \\
(0.38)\end{array}$ & $\begin{array}{l}\text { Strongl } \\
\text { y agree } \\
(0.35)\end{array}$ & $\begin{array}{l}\text { Neutral- } \\
\text { Disagre } \\
\text { e (0.35) }\end{array}$ & $\begin{array}{l}\text { Agree } \\
(0.46)\end{array}$ \\
\hline $\begin{array}{l}\text { Mandate } \\
\text { inclusion in } \\
\text { future } \\
\text { developmen } \\
\text { ts }\end{array}$ & Agree $(0.47)$ & $\begin{array}{l}\text { Agree } \\
(0.43)\end{array}$ & Agree (0.45) & Agree (0.49) & $\begin{array}{l}\text { Strongly agree } \\
(0.43)\end{array}$ & $\begin{array}{l}\text { Strongly } \\
\text { agree } \\
(0.42)\end{array}$ & $\begin{array}{l}\text { Agree } \\
(0.44)\end{array}$ & $\begin{array}{l}\text { Agree } \\
(0.49)\end{array}$ & $\begin{array}{l}\text { Agree } \\
(0.52)\end{array}$ & $\begin{array}{l}\text { Strongl } \\
\text { y agree } \\
(0.73)\end{array}$ & $\begin{array}{l}\text { Agree } \\
(0.45)\end{array}$ & $\begin{array}{l}\text { Agree } \\
(0.63)\end{array}$ \\
\hline $\begin{array}{l}\text { Type of } \\
\text { harbour use }\end{array}$ & Leisure $(0.44)$ & $\begin{array}{l}\text { Leisure } \\
(0.44)\end{array}$ & Leisure (0.44) & Leisure $(0.50)$ & Paid work (0.45) & $\begin{array}{l}\text { Leisure } \\
(0.44)\end{array}$ & $\begin{array}{l}\text { Property } \\
(0.34)\end{array}$ & $\begin{array}{l}\text { Leisure } \\
(0.47)\end{array}$ & $\begin{array}{l}\text { Leisure } \\
(0.55)\end{array}$ & $\begin{array}{l}\text { Leisure } \\
(0.53)\end{array}$ & $\begin{array}{l}\text { Transpo } \\
\mathrm{rt}(0.37)\end{array}$ & $\begin{array}{l}\text { Leisure- } \\
\text { Transpo } \\
\text { rt }(0.28)\end{array}$ \\
\hline $\begin{array}{l}\text { Frequency } \\
\text { of harbour } \\
\text { use }\end{array}$ & Living (0.31) & $\begin{array}{l}\text { Living } \\
(0.45)\end{array}$ & Living $(0.50)$ & Living (0.26) & Living (0.43) & $\begin{array}{l}2-3 \\
\text { months } \\
(0.30)\end{array}$ & $\begin{array}{l}\text { Living } \\
(0.37)\end{array}$ & $\begin{array}{l}2-3 \\
\text { months } \\
(0.25)\end{array}$ & $\begin{array}{l}\text { Living } \\
(0.40)\end{array}$ & $\begin{array}{l}1 \text { per } \\
\text { year } \\
(0.46)\end{array}$ & $\begin{array}{l}4-6 \\
\text { months } \\
(0.17)\end{array}$ & $\begin{array}{l}<1 \text { per } \\
\text { year } \\
(0.22)\end{array}$ \\
\hline $\begin{array}{l}\text { Income } \\
\text { from the } \\
\text { harbour }\end{array}$ & None $(0.42)$ & $\begin{array}{l}\text { None } \\
(0.65)\end{array}$ & None $(0.45)$ & None $(0.53)$ & None $(0.46)$ & $\begin{array}{l}\text { None } \\
(0.66)\end{array}$ & $\begin{array}{l}\text { None } \\
(0.50)\end{array}$ & $\begin{array}{l}\text { None } \\
(0.84)\end{array}$ & $\begin{array}{l}\text { None } \\
(0.57)\end{array}$ & $\begin{array}{l}\text { None } \\
(0.84)\end{array}$ & $\begin{array}{l}\text { None } \\
(0.74)\end{array}$ & $\begin{array}{l}\text { None } \\
(0.81)\end{array}$ \\
\hline $\begin{array}{l}\text { Number of } \\
\text { years living } \\
\text { by the } \\
\text { harbour }\end{array}$ & $\begin{array}{l}0->21 \text { years } \\
(0.21)\end{array}$ & $\begin{array}{l}>21 \text { years } \\
(0.39)\end{array}$ & $\begin{array}{l}21 \text { years } \\
(0.29)\end{array}$ & $0->21$ years $(0.23)$ & $>21$ years $(0.26)$ & $\begin{array}{l}0 \text { years } \\
(0.37)\end{array}$ & $\begin{array}{l}0 \text { years } \\
(0.32)\end{array}$ & $\begin{array}{l}0 \text { years } \\
(0.50)\end{array}$ & $\begin{array}{l}>21 \text { years } \\
(0.44)\end{array}$ & $\begin{array}{l}0 \text { years } \\
(0.66)\end{array}$ & $\begin{array}{l}0 \text { years } \\
(0.61)\end{array}$ & $\begin{array}{l}0 \text { years } \\
(0.51)\end{array}$ \\
\hline
\end{tabular}


Table 3: Effect size (odds ratio and confidence intervals (0.25-97.5\%)) of the relationships between the status of the harbour environment (as measured by either the cumulative impact index or the percentage of harbour shoreline modified by artificial structures) and people's perceptions of harbour health, degradation, and concern for harbour environment, support for ecological engineering and willingness to contribute to the costs of ecological engineering (see Table S5 for full details). Significant relationships are indicated in bold print.

\begin{tabular}{|c|c|c|c|c|c|c|c|}
\hline & $\begin{array}{l}\text { Perception of } \\
\text { harbour } \\
\text { health }\end{array}$ & $\begin{array}{l}\text { Perception of } \\
\text { harbour } \\
\text { degradation }\end{array}$ & $\begin{array}{l}\text { Concern for } \\
\text { the harbour } \\
\text { environment }\end{array}$ & $\begin{array}{l}\text { Support for } \\
\text { ecological } \\
\text { engineering }\end{array}$ & $\begin{array}{l}\text { Donate money } \\
\text { for ecological } \\
\text { engineering }\end{array}$ & $\begin{array}{l}\text { Pay taxes for } \\
\text { ecological } \\
\text { engineering }\end{array}$ & $\begin{array}{l}\text { Vote to ensure } \\
\text { business } \\
\text { include costs } \\
\text { of ecological } \\
\text { engineering in } \\
\text { future } \\
\text { developments }\end{array}$ \\
\hline $\begin{array}{l}\text { Cumulative } \\
\text { impact index }\end{array}$ & $\begin{array}{l}0.64(0.56- \\
0.74)\end{array}$ & $\begin{array}{l}1.46(1.31- \\
1.64)\end{array}$ & $\begin{array}{l}0.32(0.28- \\
0.36)\end{array}$ & $\begin{array}{l}1.21(0.92- \\
1.58)\end{array}$ & $\begin{array}{l}1.25(1.00- \\
1.38)\end{array}$ & $\begin{array}{l}1.11(1.00- \\
1.22)\end{array}$ & $\begin{array}{l}1.15(1.00- \\
1.28)\end{array}$ \\
\hline $\begin{array}{l}\text { Percentage of } \\
\text { harbour } \\
\text { shoreline } \\
\text { modified by } \\
\text { artificial } \\
\text { structures }\end{array}$ & $\begin{array}{l}0.98(0.96- \\
0.99)\end{array}$ & $\begin{array}{l}0.98(0.97- \\
0.99)\end{array}$ & $\begin{array}{l}1.02(1.02- \\
1.03)\end{array}$ & $\begin{array}{l}1.02(1.01- \\
1.02)\end{array}$ & $\begin{array}{l}1.01(1.00- \\
1.01)\end{array}$ & $\begin{array}{l}1.02(1.02- \\
1.02)\end{array}$ & $\begin{array}{l}1.01(1.01- \\
1.01)\end{array}$ \\
\hline
\end{tabular}


Table 4: Effect size (odds ratio and confidence interval (0.25-97.5\%)) relationships between people's connection to the harbour (as measured by type and use of the harbour, income from the harbour and years living in the harbour) and support for ecological engineering (see Table S6 for full details). Significant relationships are indicated in bold print.

\begin{tabular}{|c|c|c|c|c|c|c|c|}
\hline & $\begin{array}{l}\text { Concern for the } \\
\text { environment }\end{array}$ & $\begin{array}{l}\text { Perceived } \\
\text { knowledge of } \\
\text { the harbour } \\
\text { environment }\end{array}$ & $\begin{array}{l}\text { Support for } \\
\text { ecological } \\
\text { engineering }\end{array}$ & $\begin{array}{l}\text { Perceived } \\
\text { knowledge of } \\
\text { ecological } \\
\text { engineering }\end{array}$ & $\begin{array}{l}\text { Donate money } \\
\text { for ecological } \\
\text { engineering }\end{array}$ & $\begin{array}{l}\text { Pay taxes for } \\
\text { ecological } \\
\text { engineering }\end{array}$ & $\begin{array}{l}\text { Vote to ensure } \\
\text { business } \\
\text { include costs } \\
\text { of ecological } \\
\text { engineering in } \\
\text { future } \\
\text { developments }\end{array}$ \\
\hline Type of use & $1.29(1.23-1.35)$ & $1.44(1.37-1.52)$ & $\begin{array}{l}1.10(0.97- \\
1.25)\end{array}$ & $1.82(1.13-1.24)$ & $0.95(0.90-1.00)$ & $\begin{array}{l}1.03(0.97- \\
1.09)\end{array}$ & $\begin{array}{l}1.13(1.08- \\
1.87)\end{array}$ \\
\hline $\begin{array}{l}\text { Frequency of } \\
\text { use }\end{array}$ & $1.41(1.36-1.46)$ & $1.41(1.36-1.46)$ & $\begin{array}{l}1.01(0.93- \\
1.08)\end{array}$ & $1.08(1.05-1.11)$ & $0.92(0.89-1.00)$ & $\begin{array}{l}0.94(0.91- \\
1.00)\end{array}$ & $\begin{array}{l}1.02(0.99- \\
1.05)\end{array}$ \\
\hline $\begin{array}{l}\text { Income from } \\
\text { the harbour }\end{array}$ & $1.18(1.15-1.22)$ & $1.25(1.22-1.29)$ & $\begin{array}{l}1.02(0.94- \\
1.10)\end{array}$ & $1.06(1.03-1.09)$ & $0.94(0.92-1.00)$ & $\begin{array}{l}0.94(0.92- \\
1.00)\end{array}$ & $\begin{array}{l}1.04(1.03- \\
1.08)\end{array}$ \\
\hline $\begin{array}{l}\text { Number of } \\
\text { years living in } \\
\text { the harbour }\end{array}$ & $1.28(1.24-1.32)$ & $1.36(1.31-1.41)$ & $\begin{array}{l}1.01(0.94- \\
1.09)\end{array}$ & $1.07(1.05-1.11)$ & $0.93(0.91-1.00)$ & $\begin{array}{l}0.96(0.93- \\
1.00)\end{array}$ & $\begin{array}{l}0.97(0.94- \\
1.00)\end{array}$ \\
\hline
\end{tabular}




\section{Conflict of interest}

The authors have no actual or potential conflict of interest including any financial, personal or other relationships with other people or that could inappropriately influence, or be perceived to influence, their work 


\section{Highlights}

- Most residents have a good understanding of harbour condition.

- Concern for the environment is, however, low in degraded harbours.

- Most residents support ecological engineering but have poor knowledge of initiatives.

- To improve harbour health, greater stakeholder engagement is needed. 


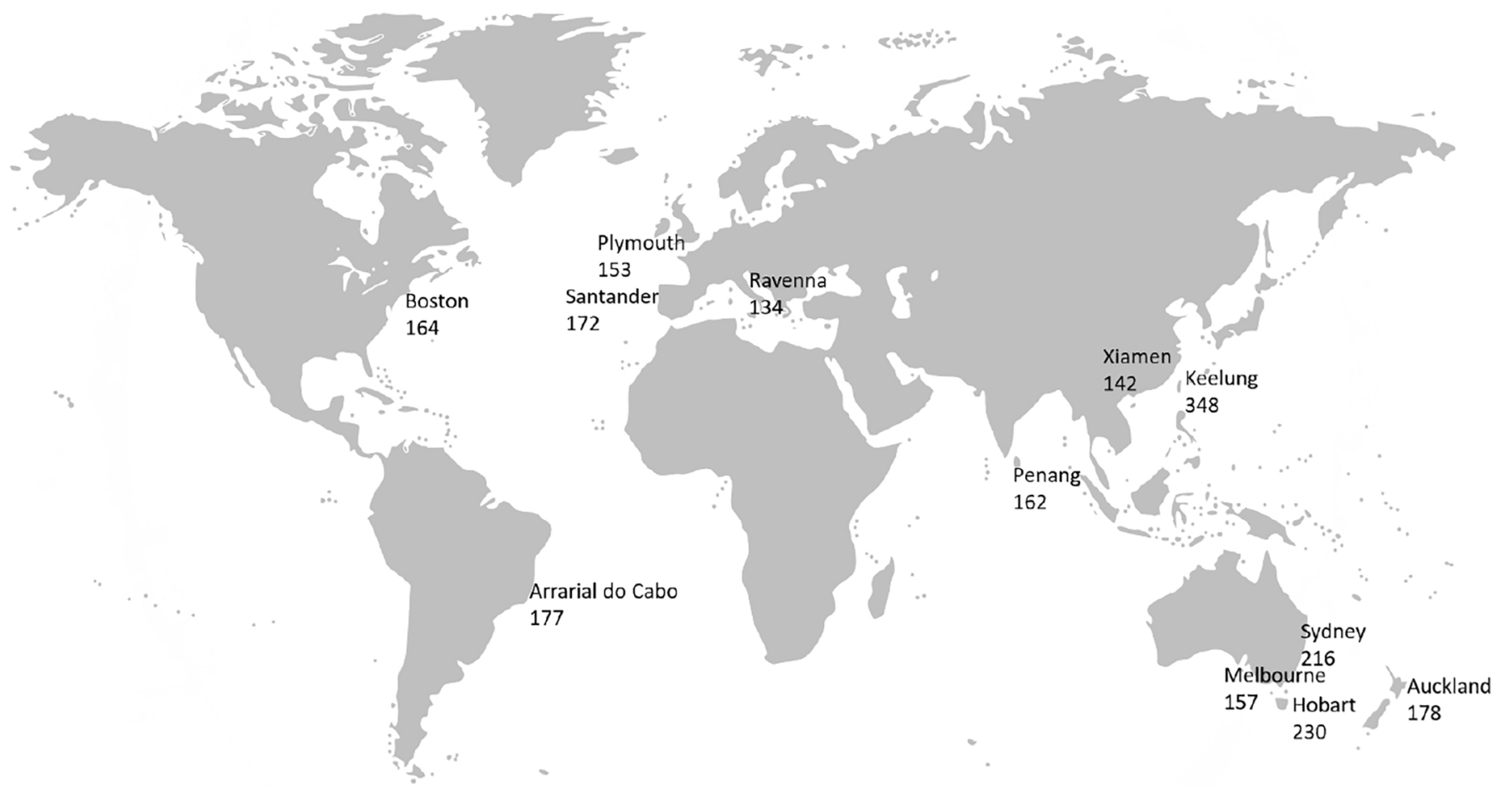

Figure 1 
a) Perception that the harbour is healthy

2.7:Auckland

3.56:Boston

3.63:Syd/Melb/Hob

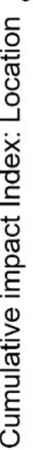

4.04:Arrarial

4.37:Santander

4.45:Ravenna

4.49:Penang

4.82: Keelung

5.08:Plymouth

5.19:Xiamen

\section{$\square$ Strongly disagree}

Disagree
Neutral

agree

- Strongly agree

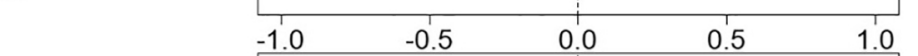

5:Arrarial

19.22: Hobart

20.57:Auckland

25:Melbourne

33:Plymouth

37.5:Penang

42:Santander

58:Boston

70:Ravenna

80:Keelung

85:Sydney

90:Xiamen

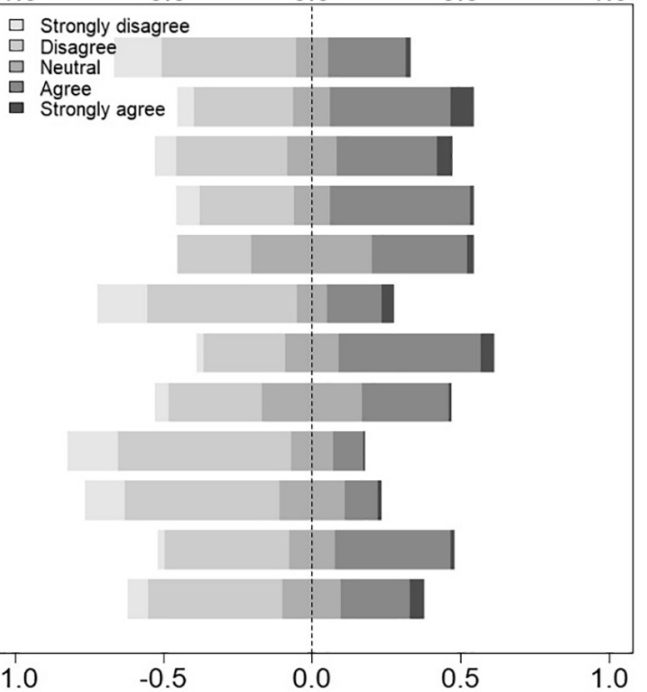

b) Perception that the harbour is degraded

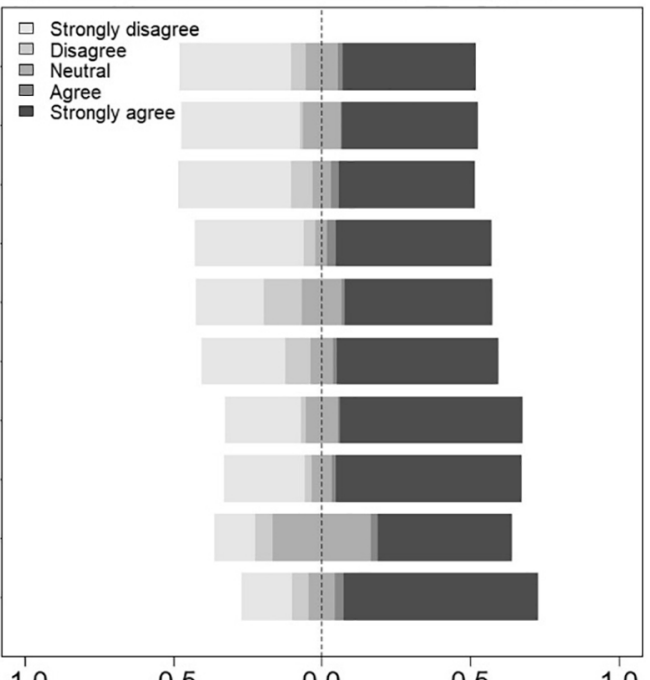

$-1.0 \quad-0.5$

$\square$ Strongly disagree
$\square$ Disagree
$\square$ Neutral

- Ngre

- Agree

0.0

0.5

1.0

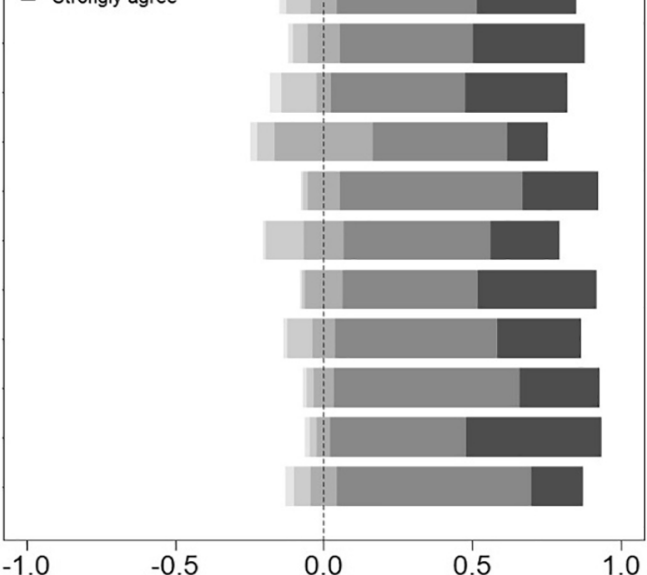

c) Concern for the harbour environment

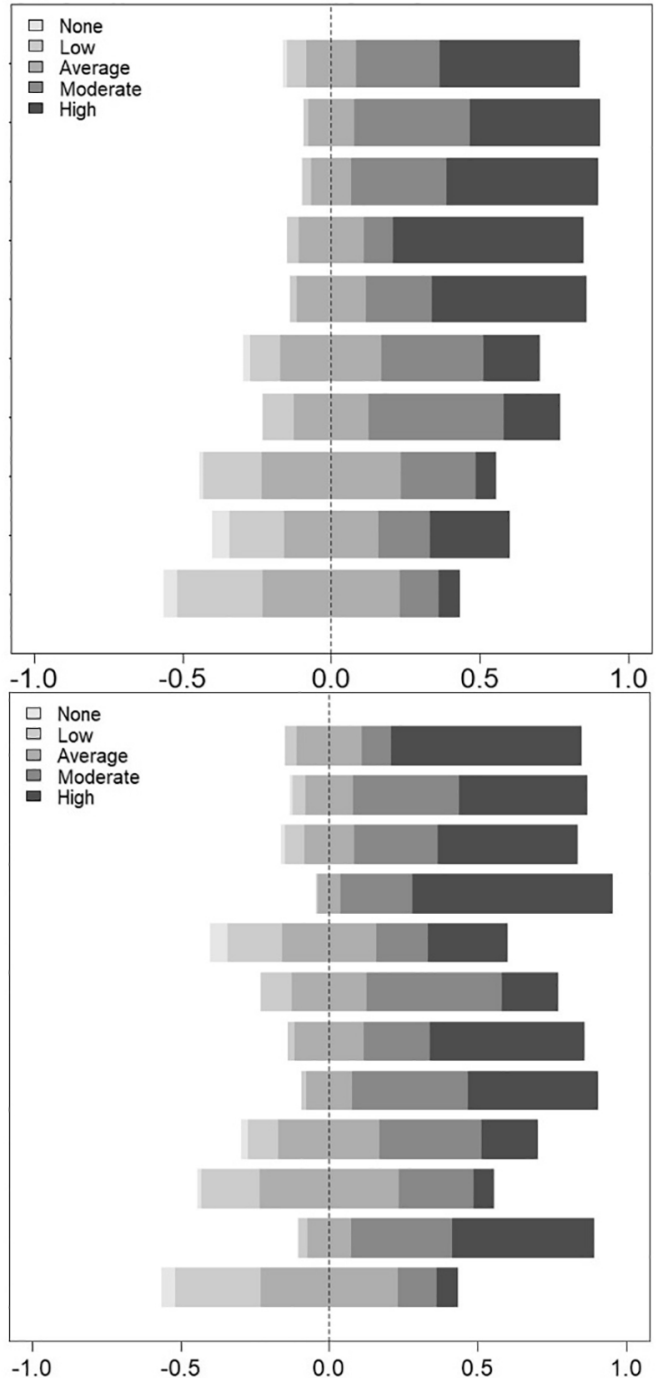

Proportion of people that disagreed (negative vales) and agreed (positive values) 
a) Concern for the environment

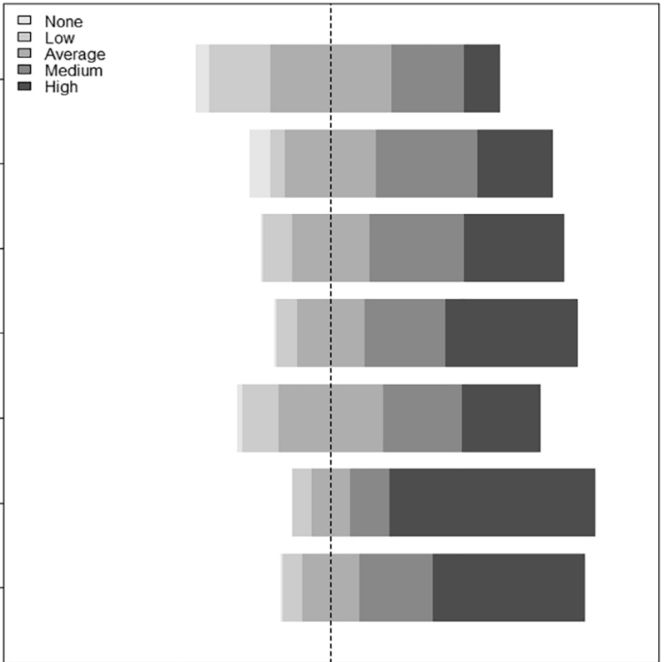

Work unpaid$$
\text { }
$$

do not use

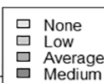

1 per year

4-6 months

2-3 months

Monthly

Weekly

Daily

I live here
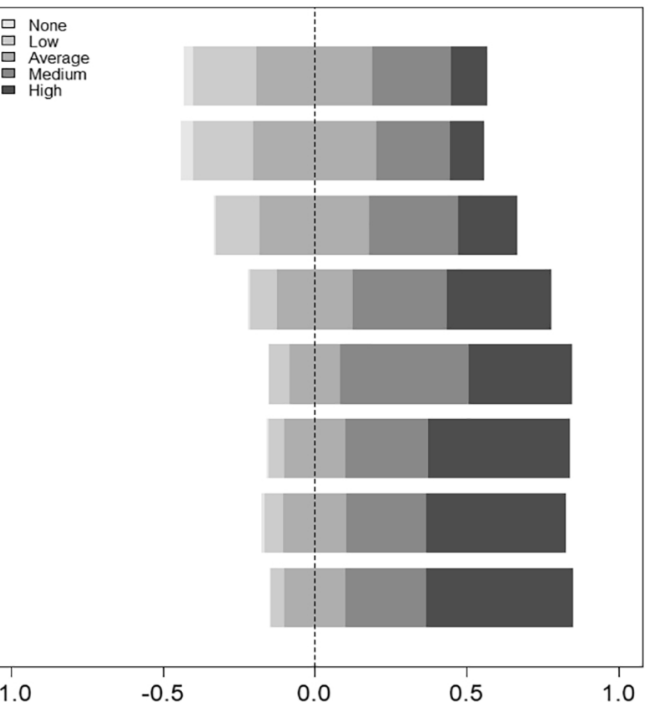

b) Knowledge of the environment
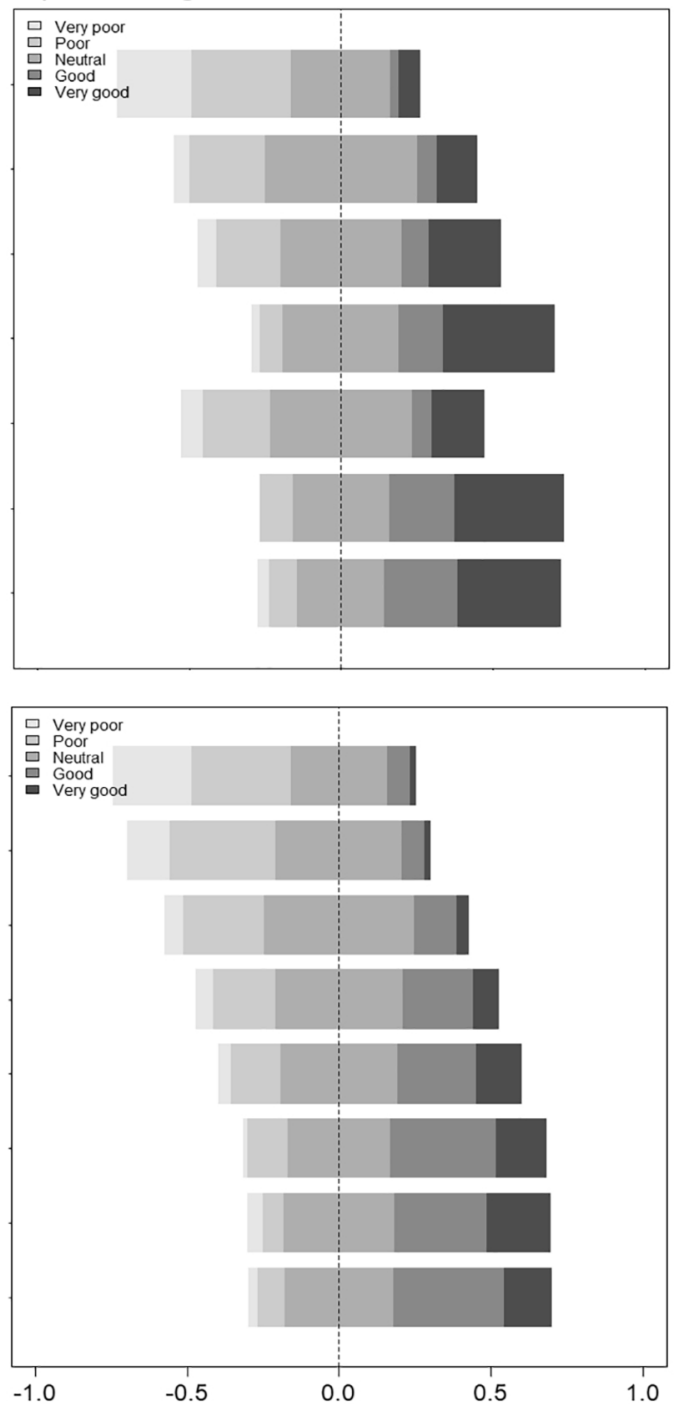

c) Knowledge of ecological engineering
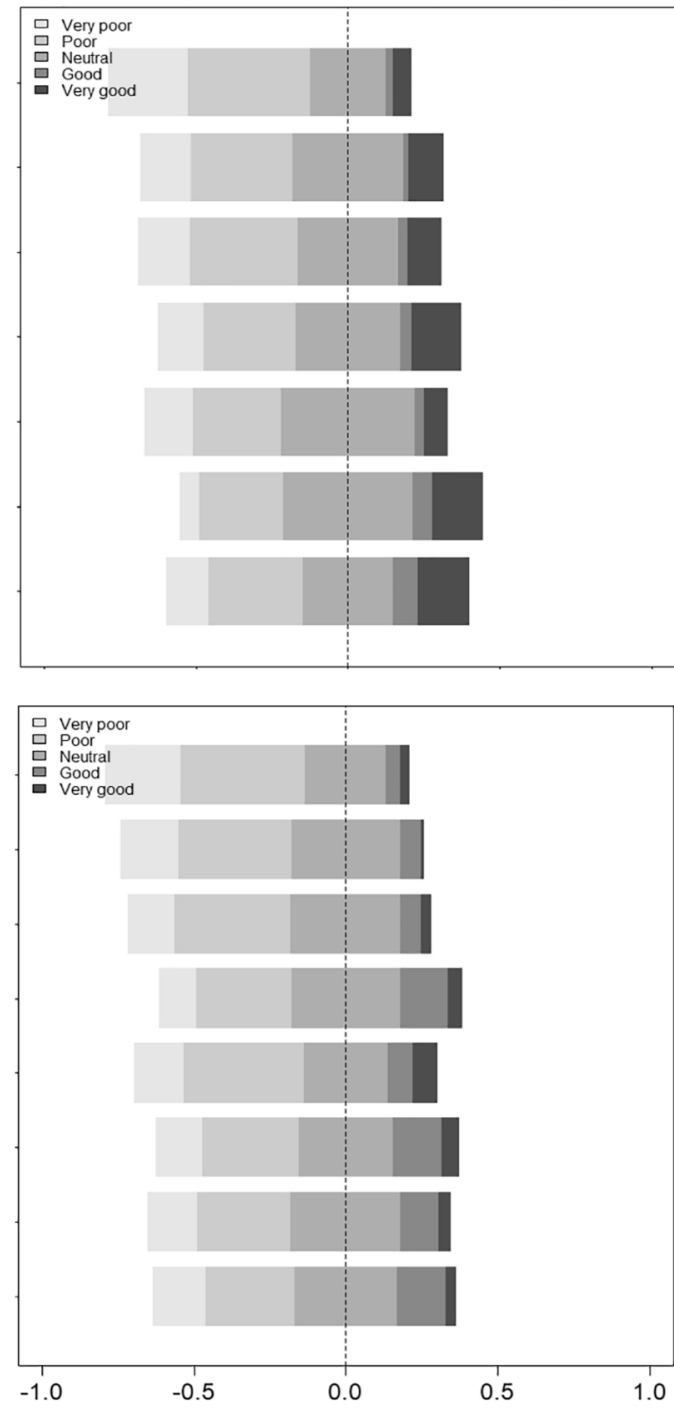

Proportion of people that disagreed (negative values) and agreed (positive values) 
a) Concern for the environment

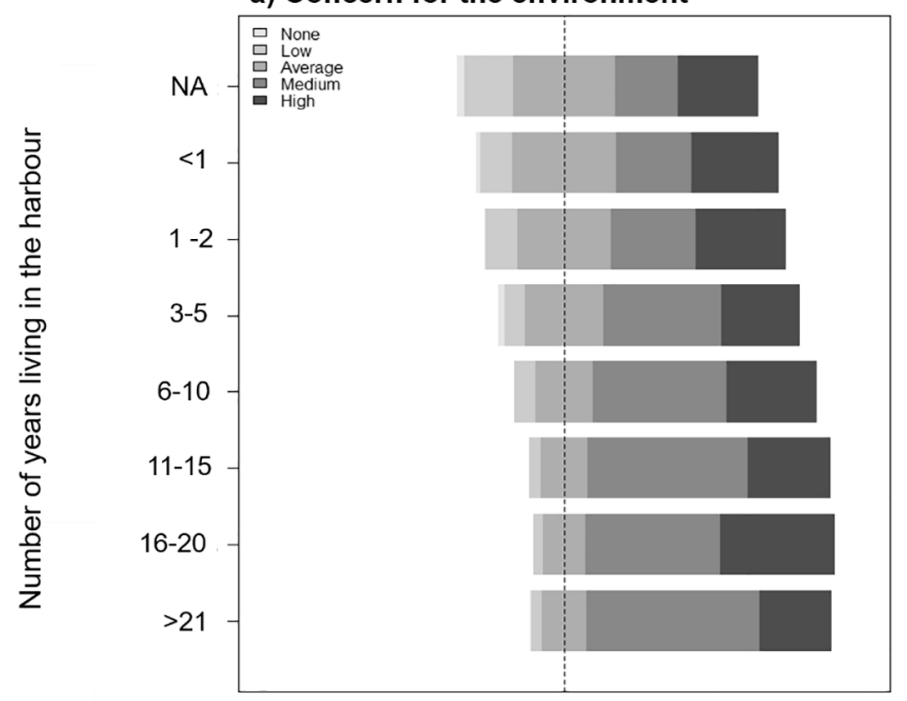

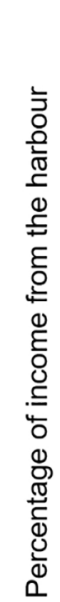

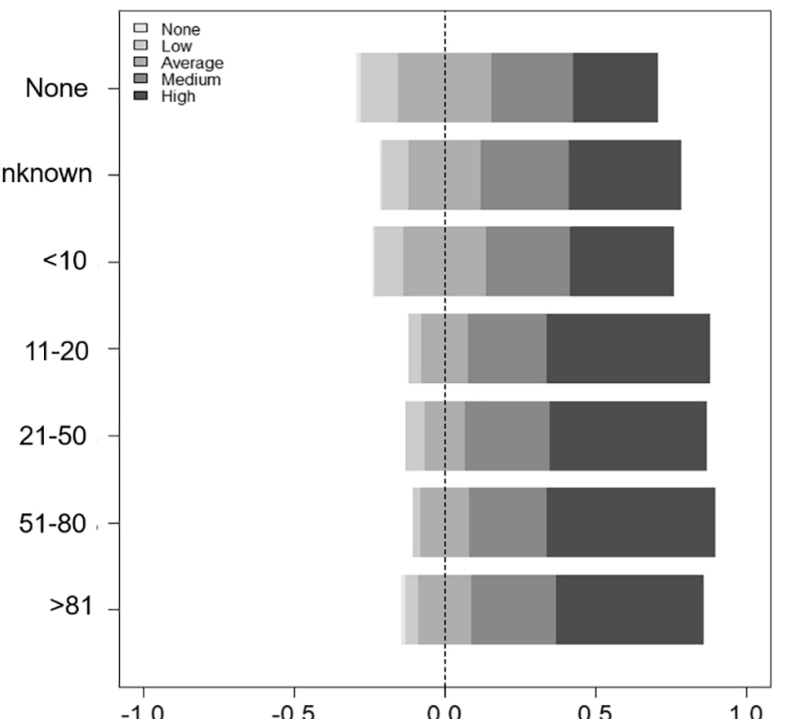

b) Knowledge of the environment
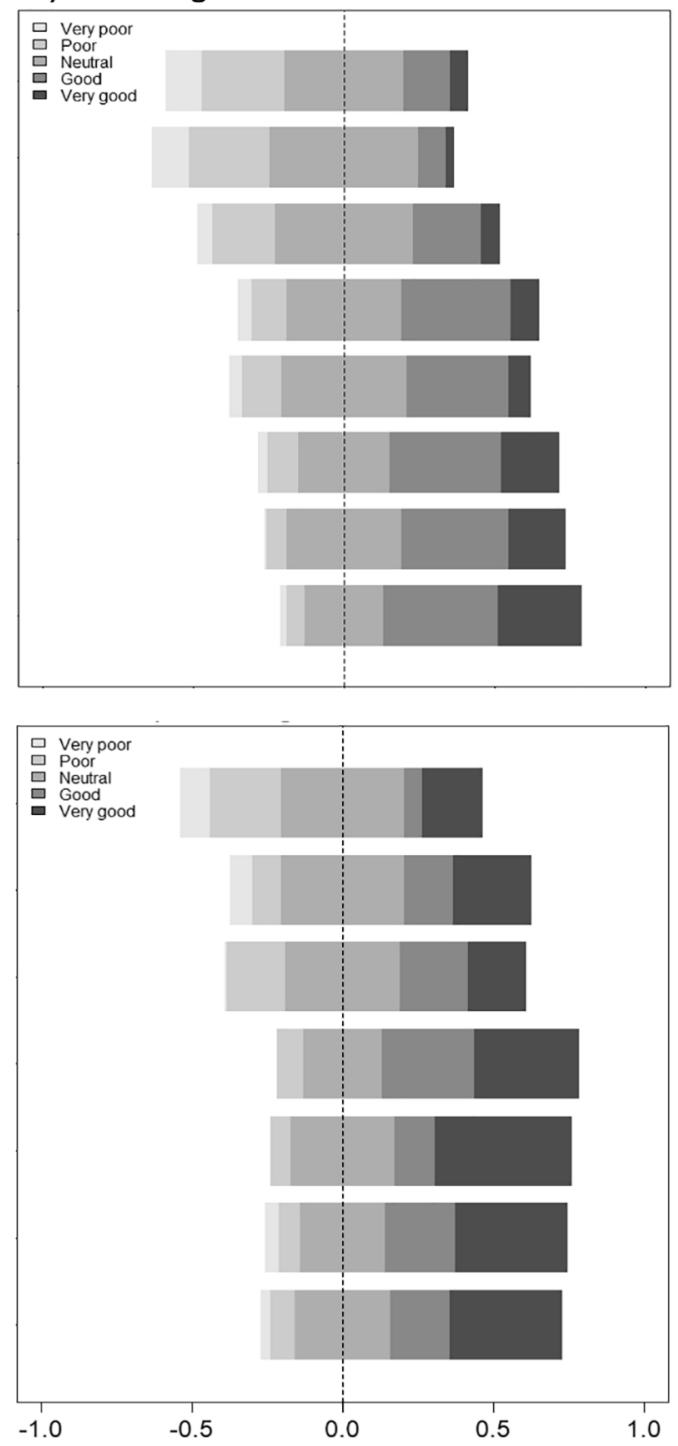

c) Knowledge of ecological engineering
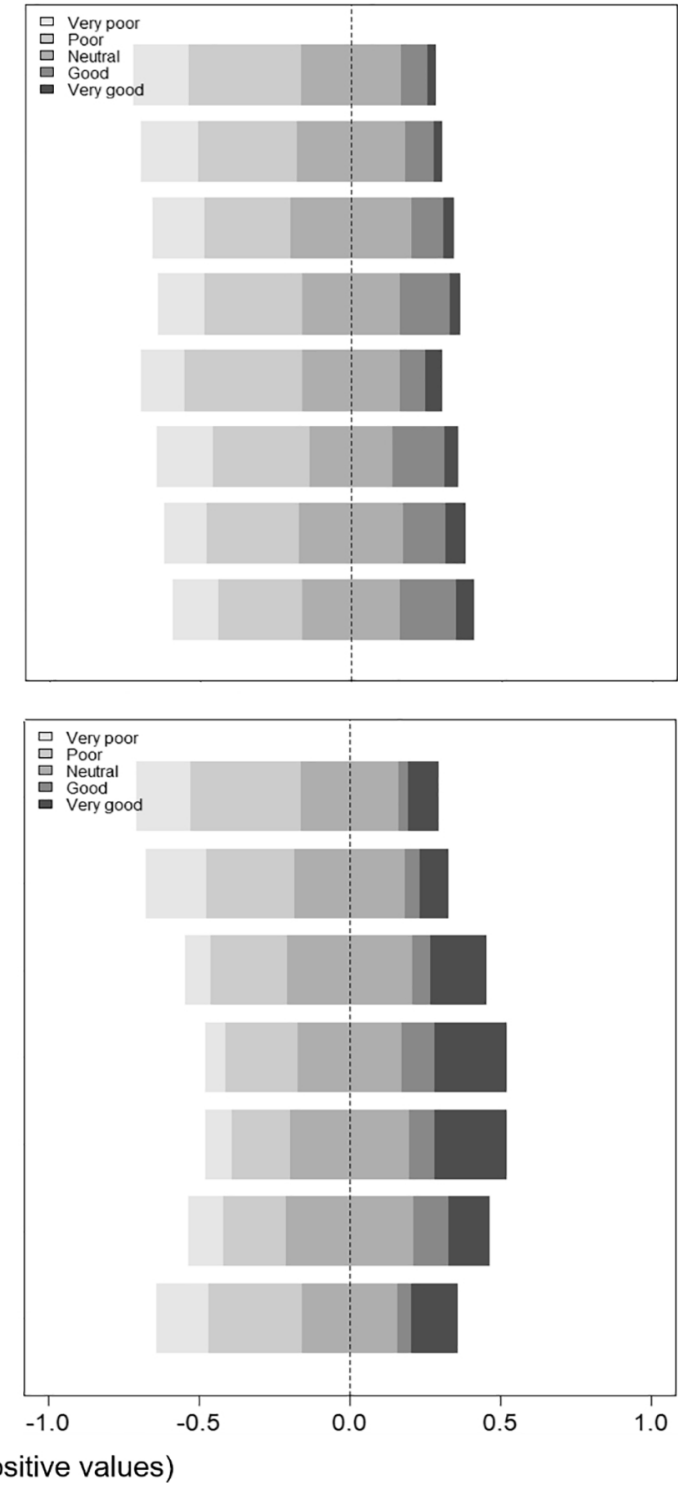